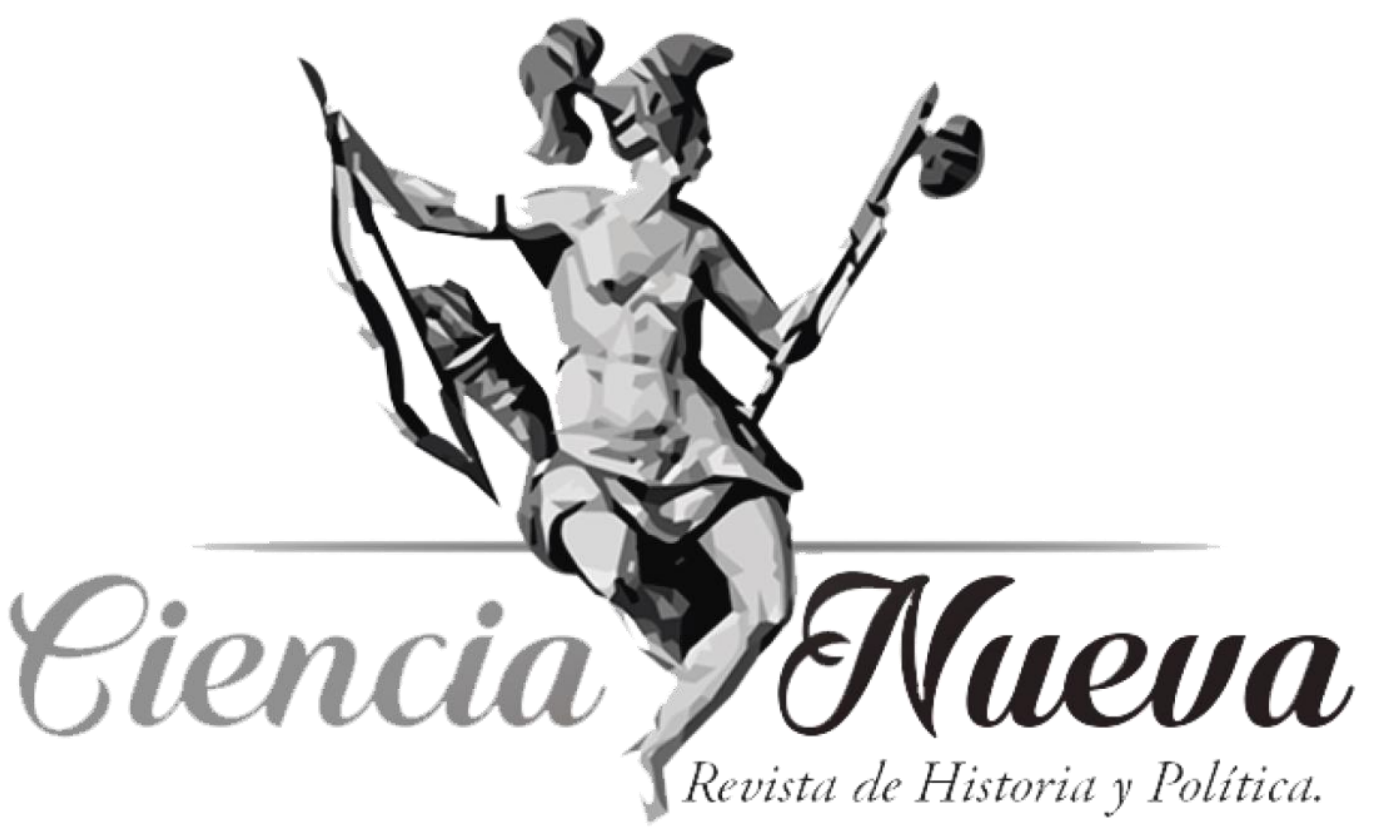

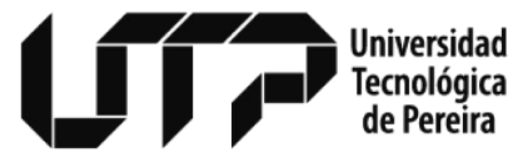

Maestría en Historia

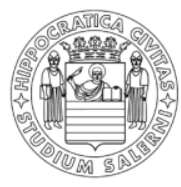

UNIVERSITÀ DEGLI STUDI DI SALERNO

Maestría en Ciencia Política

DOSSIER

GLOBAL PERSPECTIVES OF LATIN-AMERICAN HISTORY Daniel Emilio Rojas Castro (MCF), Guest Editor

\title{
LATIN AMERICA AND THE CONSTRUCTION OF A HEGEMONIC
}

PERIODIZATION

LATINOAMÉRICA Y LA CONSTRUCCIÓN DE UNA PERIODIZACIÓN HEGEMÓNICA DOI: https://doi.org/10.22517/25392662.20891

Carlos Riojas

pp. 160-193

Vol. 3 Núm. 1 | Enero-Junio de 2019

Pereira, Colombia 


\title{
LATIN AMERICA AND THE CONSTRUCTION OF A HEGEMONIC PERIODIZATION*
}

\section{LATINOAMÉRICA Y LA CONSTRUCCIÓN DE UNA PERIODIZACIÓN HEGEMÓNICA}

\author{
Carlos Riojas ${ }^{* *}$ \\ pmsvrwuc@upo.es
}

ORCID: http://orcid.org/0000-0003-3657-6004

\begin{aligned} & \hline Received: February $18^{\text {th }}, 2019 \\ &$. Reviewed: May 2 $2^{\text {nd }}, 2019 \\ &$. Accepted: June $19^{\text {th }}, 2019 \\ &$. Published: June $30^{\text {th }}, 2019 \\ &$. \hline\end{aligned}

\begin{abstract}
:
Underlying institutional factors and a type of periodization in the most influential narratives of global history contribute to the peripheralization of Latin America. The objective of this article is to learn more precisely what is being written about Latin America in two leading journals that study this continent as their main topic. I have chosen five periods and four historical events. Even though the periodization is constructed by events linked to the trajectory of the West, it offers an opportunity to situate Latin America as a key actor in a new global history.
\end{abstract}

Keywords: Global History, Latin America, Periodization, Peripheralization, Modernization.

\section{Resumen:}

Existe una serie de factores institucionales y un tipo de periodización en influyentes narrativas de historia global que contribuyen a la periferización de América Latina. El objetivo del artículo es saber de manera precisa qué se escribe sobre este continente cuando es tomado como principal objeto de estudio. Para ello escogí cinco periodos más cuatro eventos históricos. No obstante que la periodización se construyó con base en la trayectoria histórica de Occidente, ésta ofrece una valiosa oportunidad de situar a América Latina como un actor clave en una nueva historia global.

Palabras clave: historia global, América Latina, periodización, periferización, modernización.

\footnotetext{
* This research has been funded by the National Council of Science and Technology of Mexico (CONACYT). Project number: CB-2016-01- 282877. This paper was written according to the Declaration on Publication Ethics of Ciencia Nueva, Revista de Historia y Política. This Declaration can be read on the journal's website: revistas.utp.edu.co/index.php/historia.

** Assigned to the Department of Regional Studies, CUCEA, University of Guadalajara, Mexico. PhD. in Socioeconomics of development by l'École des Hautes Études in Social Sciences, Paris, France. Member of the National System of Researchers, Level I. Specialist in comparative economic history and regional economic development. Guest professor in the Department of Human Geography of the Free University of Berlin (20082009) and Faculty of Economics of the Autonomous University of San Luis Potosí, 2011-2012.
} 


\section{Introduction}

$\mathrm{T}$ There are underlying institutional factors that contribute to the peripheralization of Latin America in the most influential narratives of global history, some of which have been analyzed in other works ${ }^{1}$. Clearly, allusions are common in the specialized literature supporting a discourse on the global past that underlines a Eurocentrism, to which a Westernizing position with regard to the rest of the world is added, along with the linguisticcognitive predominance of an Anglo-Saxon perspective. Notwithstanding this preliminary set of factors, we wish to add and emphasize others that we will mention in due course ${ }^{2}$, among which the following are outstanding: how the work of global history is organized in the main centers of knowledge, as well as how this type of study constitutes an evolution of area studies in the central countries, where analytical compartmentalization is still visible at the moment of writing this type of global history that is derived from the influence or, where appropriate, the inheritance of these studies. While it is true that these analyses attempt to counteract the roots of national histories or cultural areas, it is no less true that they are encapsulated in a scientific community that regards the rest of the world as mere subject of study, not as an important interlocutor of its various interpretations. This situation ultimately leads to the construction of the other, detached from wider historical environments and with scarce interaction between them ${ }^{3}$.

Yet another factor is added to the previous discussion, which we consider crucial and controversial, but which is addressed marginally in the specialized literature. We refer to the temporal division of the phenomena studied from the perspective of the global past, that is, the periodization of a global or world history, which usually revolves around events that originate or directly impact the West in general and Western Europe in particular, resulting in the peripheralization of Latin America. The westernization of global or world history has been so notorious that it is dealt with not only in the specialized literature on the subject, but

\footnotetext{
${ }^{1}$ Carlos Riojas, “América Latina entre narrativas influyentes y tiempos de historia global”, América Latina en la Historia Económica 26, n. ${ }^{\circ} 3$ (2018): 7-39. Carlos Riojas, "Desafíos de la historia global: Una perspectiva desde América Latina", in Retos y perspectivas del desarrollo económico en Ecuador y América Latina, comp. por Instituto de Investigaciones Económicas y Políticas (Guayaquil: Centro de Investigación y Desarrollo de Ecuador - CIDE, 2017), 389-400. Matthew Brown, "The global history of Latin America", Journal of Global History 10, n. ${ }^{\circ} 3$ (2015):365-386. Jerry H. Bentley, “The Journal of World History”, in Global Practice in World History. Advances Worldwide, ed. by Patrick Manning (Princeton: Markus Wiener Publisher, 2008), 129-140. Bernd Hausberger and Erika Pani, "Historia global. Presentación”. Historia Mexicana, 68, n. ${ }^{\circ} 1$ (2018): 177-196.

${ }^{2}$ Carlos Riojas, "Luces y sombras sobre América Latina en una historia global", Esboços, Florianópolis 26, n. 41 (2019): 29-53.

${ }^{3}$ In spite of the dominant approach, there are alternative interpretations in this regard, which while it is true that they take shape with a strong Latin American inspiration, it is no less true that they recommend understanding the interconnections between diverse analytical spheres which nourish a kind of hemispheric history. As regards the cases of Latin America and Europe, the emphasis placed on the feedback between both continents is striking, which Marcello Carmagnani considers the Americanization of European elements and the Europeanization on the Indies, interconnections that will set the tone for the birth of a Euro-American space where interconnected histories will emerge globally that go beyond a linear vision of the Westernization of Latin America (Carmagnani, 2004: 402 y 406). As we have pointed out, these peculiar approaches to the global past generally arise from the Latin American sphere, and to a lesser degree from the European or Anglo-Saxon areas, a situation that has served as inspiration for this work.
} 
even in literature aimed at a larger public with diverse interests ${ }^{4}$. In spite of this, without attempting to promote a new periodization in this regard, when these periods are studied from a Latin American perspective, the contribution of this continent is not necessarily well considered in most of the more influential narratives, as we had the opportunity to verify in our bibliometric study of two leading scientific journals on the subject: Journal of World History and Journal of Global History ${ }^{5}$.

Therefore, the objective of this essay is to more precisely comprehend what is written about Latin America in the contributions of the above-mentioned journals in which Latin America is the main subject. Five historical periods suggested by Matthew Brown ${ }^{6}$ and four other historical events that we propose will be examined. Grosso modo, the first is divided as follows: the Discovery and the Conquest of America around 1500; the influence of the Atlantic world through slave economies and global trade during the second half of the $16^{\text {th }}$ century and much of the $17^{\text {th }}$ century; the late Colonial period, its crises and processes of Independence between the late $18^{\text {th }}$ and early $19^{\text {th }}$ centuries; the process of the Industrial Revolution between 1830 and 1870; the manifestation of a liberal capitalism from 1870, through the First World War until approximately 1920. To the above, we add four events that consist of the following: the Second World War and the generation of a Third World imaginary; decolonization and the rise of state economies where the influence of the Dependency Theory is projected on a global scale; the Cold War conflicts; and finally neoliberalization in various global locations based on a discourse that alludes to the free market and the processes of democratization as more efficient forms of socio-economic organization than those that went before.

While it is true that this periodization is built primarily by events linked to the historical trajectory of the West, it is no less true that it offers a valuable opportunity to place Latin America as a key, though not unique actor in a new global history. By examining an overview of the articles that take Latin America as their main theme, appearing in the Journal of World History from 1990 to 2018-I and in the Journal of Global History from 2006 to 2018, we will demonstrate this perspective.

To achieve this objective, we have divided the texts into three sections. In the first we present other proposals for periodization in order to see to what extent the temporal division suggested here is compatible with other historical time periods in global discourses. In the second part, the first five periods suggested by Brown ${ }^{7}$ are set forth, in light of the contributions of the Journal of World History and Journal of Global History that have a certain historical-global aspect of Latin America as their main theme, which gives some sense to the periodization suggested by this author. Finally, we include the four above-mentioned events in the discussion, noting that while they could be considered as periods, we decided not to present them as such because many of the phenomena associated with them overlap in time. Both the set of these events and their periodization are inscribed in a historical trajectory with a Western perspective. Even so, at the same time this offers us a valuable opportunity to position Latin America as a key actor, even if that doesn't mean it is unique, as Carmagnani

\footnotetext{
${ }^{4}$ Alain Bihr, “Oú est née la mondialisation? 'Histoire globale' berceau occidental”. Le Monde Diplomatique, Septembre 2018, consulted Septembre 24th 2018, https://www.monde-diplomatique.fr/2018/09/BIHR/59013. 2018.

${ }^{5}$ Riojas, "América Latina entre narrativas influyentes y tiempos de historia global”.

${ }^{6}$ Brown, "The global history of Latin America".

${ }^{7}$ Brown, "The global history of Latin America".
} 
demonstrated, in the construction of a new history of truly global dimensions ${ }^{8}$. The text concludes with some final considerations.

\section{Temporal Divisions in Global Discourses}

Before addressing the periods indicated in the previous section in greater detail, it is important to briefly review other proposals of temporal divisions, which, while they do not offer as extensive a periodization as the one presented here, they do touch on different periods with a varied emphasis which in some measure coincide with what Brown suggested and with the extension that we outlined ${ }^{9}$. These proposals also reflect, to varying degrees an institutional influence linked to the Anglo-centric vision, be it global history or the history of globalization, where the peripheralization of Latin America, inherent to these influential narratives, is an underlying phenomenon.

In one of the works that has become a reference in the field of global history studies, Bayly proposed various phases of the globalization process with an emphasis on the birth of what he considers the modern world ${ }^{10}$; this is understood as the boom of the Nation-State, centralized on the basis of loyalty or ethnic solidarity that developed a series of economic and intellectual links at the planetary level ${ }^{11}$. Even though the origins of modernization can be sought in the fifteenth century, from a Latin American perspective, what Aldo Ferrer called the First World Economic Order ${ }^{12}$, the crucial stage of the modern world appeared in the $19^{\text {th }}$ century. The first of these phases, Bayly noted, is archaic globalization, consisting of the operation of old networks and forms of domination derived from the diffusion of ideas, with a range of action inscribed in the local-regional; this phase would conclude around 1750; furthermore, it gave rise to a process of uniformization, which our author distinguished from homogenization $^{13}$.

A second phase is a proto-capitalist globalization, which on the one hand would reinforce the links already established in archaic globalization while on the other, would rely on new phenomena such as the so-called Industrial Revolution or the Industrious Revolution. The latter concept, derived from Jan de Vries' original proposal ${ }^{14}$, is referenced by Bayly on several occasions and places Western Europe and North America as key players, regardless of the type of revolution he refers to. It is important to note that this period covers the years between 1750 and 1830, although some of its characteristics would overlap with the period that followed ${ }^{15}$.

The third phase identified by Bayly, in other words, the one where it is clear that a modern world is underway, would be characterized by unequal economic growth that challenges the various forms of power. Along with industrialization, various metropolises emerged as centers of indisputable power or, if you prefer, the centers of world-economy as conceived by Fernand Braudel which would harbor imperialist expansionist pretensions in

\footnotetext{
${ }^{8}$ Marcello Carmagnani, El otro occidente. América Latina desde la invasión europea hasta la globalización (Mexico: FCE, 2004).

${ }^{9}$ Matthew Brown, "The global history of Latin America".

${ }^{10}$ C.A. Bayly, La naissance du monde moderne (Paris: Editions de l'Atelier/ Éditions Ouvrières, 2007).

${ }^{11}$ Bayly, La naissance du monde moderne, 34.

${ }^{12}$ Aldo Ferrer, Historia de la globalización. Orígenes del orden económico mundial (México: FCE, 1996$), 14$.

${ }^{13}$ Bayly, La naissance du monde moderne, 37, 47, 55, 76.

${ }^{14}$ Jan De Vries, "The industrial revolution and the industrious revolution", Journal of Economic History 54, n. o 2 (1994): 249-270.

${ }^{15}$ Bayly, La naissance du monde moderne, 81,87, 91.
} 
the light of an intransigent nationalism ${ }^{16}$. The rise of multiple ideas would be observed during this phase, such as liberalism, rationalism, socialism and scientific knowledge, this stage would extend from approximately 1830 until the beginning of the First World War in $1914^{17}$.

Along this same line of periodization proposals, from a more Latin American perspective, Bernd Hausberger suggested in his Historia mínima de la globalización temprana (Minimal History of Early Globalization) a regressive periodization that at a given time coincides with Bayly's third phase, as a sort of long $19^{\text {th }}$ century, which would begin in 1870 and lasted until the First World War (1914-1918), with the proviso that the crisis of 1929 be included in this time period ${ }^{18}$. Subsequently, this same author proposed that the $18^{\text {th }}$ century's key events would be the Industrial Revolution and the rise of European hegemony ${ }^{19}$, however in practical terms this refers to the end of the $18^{\text {th }}$ century and the beginning of the next one. Then we have the $17^{\text {th }}$ century, where the starting period coincides with the chronological principle of the same (1600); this also underlines a European crisis that is generalized globally through famines, wars, rebellions, etc. and it includes the fragmentation of empires, the golden age of the Low Countries, as well as the differentiation between East and West. Finally, we have the $15^{\text {th }}$ century and its antecedents $(-1500)$, highlighting European expansion, the discovery and the conquest of America, as well as the flows of precious metals, and other phenomena ${ }^{20}$. In general terms, it coincides with some of the periodization proposals mentioned so far.

Finally, we also find periodization proposals for what we would call a recent globalization whose periods have not been of interest for the authors mentioned so far but which are crucial for our argument in general. In a working paper Thomas I. Palley proposed three periods for a modern globalization associated with commercial flows in contrast to the generalized idea as argued by this author, that there are only two phases ${ }^{21}$. That is, it was originally thought that the first phase began in 1870 up to the debut of the First World War in 1914 (here he coincides with both Bayly and Hausberger) ${ }^{22}$, and the second began in 1945 up to the present. It should be noted that there is an intermission in this classification (19151944), but even so, international trade is seen as the best organizer of world production during the entire period being contemplated. Therefore, the reinterpretation would include the same above-mentioned first period of 1870-1914 known as Victorian globalization, a second globalization period from 1945 to 1990 known as Keynesian globalization with the intermission we pointed out persisting, and finally the third globalization period from 1990 to date, which Palley called neoliberal globalization ${ }^{23}$. In this proposal, it is clear to us how global time or globalization time is organized in terms of a Euro-Anglo-centrist imaginary, as we have already explained in other parts of this work.

\footnotetext{
${ }^{16}$ Fernand Braudel, La dynamique du capitalisme (Paris: Champs-Flammarion, 1985).

${ }^{17}$ Bayly, La naissance du monde moderne, 276, 279, 305, 327.

${ }^{18}$ Bernd Hausberger, Historia mínima de la globalización temprana (México: El Colegio de México, 2018), 24.

${ }^{19}$ Hausberger, Historia mínima de la globalización ..., 25-28.

${ }^{20}$ Hausberger, Historia mínima de la globalización ..., 28-38.

21 Thomas I. Palley, "Three globalizations, not two: Rethinking the history and economics of trade and globalization", FMM Working Paper 18 (2018), March Hans-Böckler Stiftung.

22 Bayly, La naissance du monde moderne. Hausberger, Historia mínima de la globalización.

${ }^{23}$ Palley, "Three globalizations, not two: Rethinking the history and economics of trade and globalization", 5.
} 


\section{Historical Periods and Multiple Interconnections}

Although the persistence in different degrees of an imaginary anchored to the organization of global times in terms of economic issues is relatively evident in the suggestions of periodization set forth in the previous section, we want to emphasize this point because the imbrication of other spheres (political, cultural, geographical or social areas, for example) is also obvious. Even so, when the periods exposed are viewed in a general perspective, they give a certain sense to Brown's periodization suggestion ${ }^{24}$. We will return now to this latter suggestion based on what has been said so far.

The first period alluded to by Brown, is located around 1500 and covers part of the process that resulted in the discovery by Europeans of the Americas and the Conquest, events closely associated with the initial contacts established by the voyages of Christopher Columbus. The articles that analyze this period contended that these trips became a source of global transformation with passages that were not necessarily monodirectional or following a single route ${ }^{25}$. This situation illustrates the role played by a series of tangible and intangible resources that accompanied these flows; of significance the construction of an environmental and geographical imaginary. Notably, this imaginary was at first attached to the biblical representations of the Paradise that they alluded to ${ }^{26}$. But the Caribbean was more than an idyllic archipelago, it represented a vast heritage of new opportunities that was not only difficult for Europeans to fully exploit in the first years of contact, but also for Asians. Even so, the conquerors tried to impose their ideas and redesign a new geography whose limits or borders have been characterized over time by their porosity ${ }^{27}$, as was the case with other spaces, such as Africa ${ }^{28}$.

However, the redesigning of these limits has not only been physical or geographical; additional intangible manifestations based around a set of ideas that later became specific practices becomes obvious. One evidence of this is the Renaissance, which could well be conceived of as a purely European manifestation and a product of early modernity. However, there are studies that show how this phenomenon was a result of feedback from other cultural expressions with an impact of a global nature. In the case of America, hybridization exists that transcends simple domestication, syncretism or translation ${ }^{29}$. Additionally, another example is the urban influence exercised by the Tenochtitlán grid structure, which not only extended throughout the Americas, but is part of a specific conception of city structure with a global impact. Within this same intangible group of factors, the specific case of the Spanish is illuminating, because they were inspired by a set of formal and informal institutions of feudal origin which, in one way or another, sought to justify the Conquest worldwide and the mechanisms deployed to dominate the multiple indigenous populations that inhabit the

\footnotetext{
${ }^{24}$ Matthew Brown, "The global history of Latin America”. Journal of Global History 10, n. 3 (2015): 365 386.

${ }^{25}$ Nancy E. Van Deusen, "Indios on the move in the sixteenth-century Iberian world", Journal of Global History 10, n. ${ }^{\circ} 3$ (2015): 387.

${ }^{26}$ William D. Jr. Phillips, “Africa and the Atlantic islands Meet the Garden of Eden: Christopher Columbus's View of America”, Journal of World History 3, n. 2 (1992):149-153.

${ }^{27}$ Robert Finlay, "How Not to (Re) Write History: Gavin Menzies and the Chinese Discovery of America", Journal of World History 15, n. ${ }^{\circ} 2$ (2004): 229.

${ }^{28}$ Susan D. Amussen and Allyson M. Poska, "Restoring Miranda: gender and the limits of European patriarchy in the early modern Atlantic world", Journal of Global History 7, n. ${ }^{\circ} 3$ (2012): 343.

${ }^{29}$ Peter Burke, Luke Clossey and Felipe Fernández-Armesto, "The global Renaissance”, Journal of World History 28, n. ${ }^{\circ} 1$ (2017):18-19.
} 
Americas $^{30}$; for some authors the fall of Tenochtitlán unleashed the demons and angels of globalization $^{31}$. From then on, oceans, family ties, commercial strategies and politicalmilitary initiatives shaped this particular global scenario beyond imperial or continental confines. Ecosystems also impacted the dynamics of human settlements, which according to the research of Crosby generated similar patterns of population density between certain areas such as the Central Valley of Mexico and the Yangzi Valley, whose panoramas were transformed due to epidemiological, military and political phenomena that, taken as a whole, gave evidence of the degree of complexity derived from contact between different societies ${ }^{32}$. Despite the changes manifested globally, it is striking that cultural practices still persist among the Nahuas, Mayas, Mixtecs or Zapotecs that account for the importance of local or other histories ${ }^{33}$, which have not always been studied in a way that is interconnected with events of greater magnitude.

In the second period, the proliferation of slave economies is emphasized. However, we believe that it would be more appropriate to address the influence and complexity acquired by the Atlantic world itself and trans-Pacific trade, which includes the above-mentioned economies as one of its key elements. The repercussions of the above were not only felt in Latin America, but also in the Americas in general, Europe, Asia and Africa. The boom of the Atlantic world, conceived as a metaphor that alluded to one whole, was manifested in global terms from the second half of the $16^{\text {th }}$ century and much of the $17^{\text {th }}$ century. The flow of exchanges contained people, knowledge, practical information, medicinal products, raw materials and living beings among other goods. Some transactions were made legally, others illegally according to the prevailing institutional context of each period and the space in question $^{34}$. In this sense, natural products stood out, which served to compare the flora, fauna and minerals known in Europe with those found in the Americas, a situation that expanded the possibilities for interchange and intensification of circuits of knowledge, not only in the field of medicine for example, but also in that of natural history that opened up with these new perspectives ${ }^{35}$. In no way can these flows be conceived, neither in the Atlantic or in the Pacific, as neutral elements; instead they formed part of a system of domination whose essential peculiarity was non-definition, or in its absence, dispute over a "geometric center"36, in the context of a decentralized geography of knowledge. Through these exchanges the construction and implementation of powerful empires came about, empires that relied on

\footnotetext{
30 James Muldoon, “Solorzano's 'De indiarum iure': Applying a Medieval Theory of World Order in the Seventeenth Century", Journal of World History 2, n. ${ }^{\circ} 1$ (1991): 30. Patricia Lopes Don, "Franciscans, Indian Sorcerers, and the Inquisition in New Spain, 1536-1543”, Journal of World History 17, n. ${ }^{\circ} 1$ (2006): 27.

31 Álvaro Enrigue, "The curse of Cortés". The New York Review of Books, May 24th 2018, consulted May 25th 2018, https://www.nybooks.com/articles/2018/05/24/mexico-curse-of-cortes.

${ }^{32}$ Alfred W. Crosby, "Infectious Disease and the Demography of the Atlantic", Journal of World History 2, n. o 2 (1991):119-120.

${ }^{33}$ Frances Karttunen, “After the Conquest: Survival of Indigenous Patterns of Life and Belief", Journal of World History 3, n. ${ }^{\circ} 2$ (1992): 242.

${ }^{34}$ Bethany Aram, "Caribbean ginger and Atlantic trade, 1570-1648”, Journal of Global History 10, n. ${ }^{\circ} 3$ (2015): 410. Paula Susan De Vos, "The Science of Spices: Empiricism and Economic Botany in the Early Spanish Empire", Journal of World History 17, n. ${ }^{\circ} 4$ (2066): 399.

${ }^{35}$ Irina Podgorny, "The elk, the ass, the tapir, their hooves, and the falling sickness: a story of substitution and animal medical substance", Journal of Global History 13, n. ${ }^{\circ} 1$ (2018): 47-48.

${ }^{36}$ Luke Clossey, "Merchants, migrants, missionaries, and globalization in the early-modern Pacific", Journal of Global History 1, n. ${ }^{\circ} 1$ (2006): 41.
} 
their technological, military and, therefore naval superiority ${ }^{37}$. All of the above cannot be fully understood without the link that produced the discovery for Europeans and the conquest of the Americas in interconnection with the participation of Asia and Western Europe, phenomena that gradually designed specific spaces of action and reaction ${ }^{38}$. As regards the intangible elements, life trajectories can be included that shaped many of the relationships that have been pointed out, some characterized by remarkable masculinity ${ }^{39}$. But above all, there was an obvious proliferation of an alterity that entailed in itself sentimental manifestations of fear, dread, love or, failing that, violent and destructive acts, including certain fixations ${ }^{40}$, to which the outbreak of diverse identities or specific patterns of behavior $^{41}$ was added as an apparent limit to this early modernity that came into contact with multiple phenomena of a local nature ${ }^{42}$. It is important to mention in particular the expansion of Christianity ${ }^{43}$ as a powerful weapon of Westernization, generating specific values and behaviors that left a deep imprint on Latin American identities. In a concrete way we can refer to what are known as flores sanctorum in Catholic culture, that is, collections of stories about the lives of saints, written in regular European languages that were spread globally, especially by Jesuit and Franciscan orders, as part of the propagation of a religious imaginary that tried to slowly impose itself in diverse parts of the world, as was the case of China ${ }^{44}$, where the experiences acquired by Jesuits in Latin America were essential ${ }^{45}$

The third period includes the late colonial period that would roughly encompass the processes of Independence, between the last and the first quarter of the $18^{\text {th }}$ and $19^{\text {th }}$ centuries respectively; events that marked the construction of national identity in Latin America through a discussion that gave greater weight to modernity with respect to coloniality ${ }^{46}$. The referential framework of this modernity is inscribed in a Western, universal, totalizinggeneralizable, and humanist type of thought which projects certain hierarchies, dominations and alterities ${ }^{47}$. The roots of this thought have been so deep that the Enlightenment and

\footnotetext{
${ }^{37}$ William R. Thompson, "The Military Superiority Thesis and the Ascendancy of Western Eurasia in the World System", Journal of World History 10, n. ${ }^{\circ} 1$ (1999): 143.

${ }^{38}$ Baki Tezcan, "Law in China or Conquest in the Americas: Competing Constructions of Political Space in the Early Modern Ottoman Empire”, Journal of World History 24, n. ${ }^{\circ} 1$ (2013): 107.

${ }^{39}$ Ulrike Strasser, "A case of empire envy? German Jesuits meet an Asian mystic in Spanish America”, Journal of Global History 2, n. ${ }^{\text {o }} 1$ (2007): 24.

${ }^{40}$ Melanie Pareault, "To Fear and to Love Us': Intercultural Violence in the English Atlantic", Journal of World History 17, n. ${ }^{\circ} 1$ (2006): 71. Colin A. Palmer, "From Africa to the Americas: Ethnicity in the Early Black Communities of the Americas", Journal of World History 6, n. ${ }^{\circ} 2$ (1995): 223.

${ }^{41}$ H.E. Martel, "Hans Staden's Captive Soul: Identity, Imperialism, and Rumors of Cannibalism in SixteenthCentury Brazil”, Journal of World History 17, n. ${ }^{\circ} 1$ (2006): 51.

${ }^{42}$ Lauren A. Benton, "The Legal Regime of the South Atlantic World, 1400-1750: Jurisdictional Complexity as Institutional Order”, Journal of World History 11, n. ${ }^{\circ} 1$ (2000): 27.

${ }^{43}$ Dauril Alden, "Changing Jesuits Perception of the Brasis During the Sixteenth Century", Journal of World History 3, n. ${ }^{\circ} 2$ (1992): 205.

44 José Antonio Cervera and Ricardo Martínez Esquivel, "Puebla de los Ángeles, entre China y Europa. Palafox en las controversias de los ritos chinos", Historia Mexicana 68, n. ${ }^{\circ} 1$ (2018): 251.

45 Jonathan Greenwood, "Readable flowers: global circulation and translation of collected saints' lives", Journal of Global History 13, n. ${ }^{\circ} 1$ (2018): 23, 28.

46 Walter D Mignolo, Historias locales/diseños globales. Colonialidad, conocimientos subalternos y pensamiento fronterizo (Madrid: Akal, 2003), 13.

${ }^{47}$ Christina Schramm, "Estado, justicia y libertad. Aportes al pensamiento político desde Ditsö Káska y la diáspora africana", Anuario CIEP 4 (2014): 26. Sanjay Subrahmanyam, "Connected history: notes towards a reconfiguration of early modern Eurasia”, Modern Asian Studies 31, n. ${ }^{\circ} 3$ (1997): 739.
} 
Civilization are used as interchangeable and universal concepts and points of reference ${ }^{48}$. Empirical evidence of this modern thought adapted to local conditions was the slave rebellion in Haiti in 1793. Allusion was made at that time to ideas derived from the French Revolution, mixed with monarchical feelings of African origin ${ }^{49}$. In spite of this, the flow of slaves to the Americas continued until the mid $19^{\text {th }}$ century, not without questioning by modernist arguments that, in the best of cases, related it to the great migratory movements ${ }^{50}$.

On the other hand, the emergence of alternate visions sustained in the continental, shows that the predominance of the national was not absolute; the continental metaphor ${ }^{51}$ contributed to contextualizing the nation based on broader geographic categories. It also served as another sphere of more extensive action that served to articulate a political discourse and a scientific perspective that transcended the recent national borders in the face of the imperialist winds blowing from the north ${ }^{52}$. From an endogenous point of view, other configurations were also revealed; for example, concepts such as race, class and gender flourished; they even highlight elements of a modernizing discourse that abstractly divided the territory between a seemingly modern city and, in principle a traditional countryside ${ }^{53}$.

Likewise, other institutional dynamics contributed to this spatial design through fiscal or monetary systems that were conceived from an imperial perspective, but which in turn fed national identities in the face of crises of legitimacy, interdependence of tax collection policies and economic growth ${ }^{54}$. Last, but not of least importance, the world of exchanges stands out, where American silver is traditionally seen as a catalyst of trade between Asia and Europe, but which also helped delineate alternative trade routes, such as the route that was maintained between Mexico and the Philippines ${ }^{55}$, that has been seen as a non-traditional exchange because it does not directly connect a "center" and a "periphery" but rather contributes to the processes of miscegenation and modernization simultaneously. Based on this, it is feasible to reconstruct other spaces that surpass the limits of the transactions carried out in the Atlantic ${ }^{56}$ or, failing that, they illustrate inter-imperial dynamics, as a kind of

\footnotetext{
48 Sebastian Conrad, "Enlightenment in global history: A historiographical critique", American Historical Review 117, n. ${ }^{\circ} 4$ (2012): 1019.

49 John K. Thornton, "I am the Subject of the King of Congo": African Political Ideology and the Haitian Revolution», Journal of World History 4, n. ${ }^{\circ} 2$ (1993): 181-182.

${ }^{50}$ John A. E. Harris, "Circuits of wealth, circuits of sorrow: financing the illegal transatlantic slave trade in the age of suppression, 1850-66”, Journal of Global History 11, n. 3 (2016): 409.

${ }^{51}$ James David Drake, "Appropriating a Continent: Geographical Categories, Scientific Metaphors, and the Construction of Nationalism in British North America and Mexico”, Journal of World History 15, n. 3 (2004): 323.

${ }^{52}$ Michel Gobat, "The Invention of Latin America: A Transnational History of Anti-Imperialism, Democracy, and Race", The American Historical Review 18, n. ${ }^{\circ} 5$ (2013): 1345.

${ }^{53}$ Philip D Curtin, "Location in History: Argentina and South Africa in the Nineteenth Century", Journal of World History 10, n. ${ }^{\circ} 1$ (1999): 41.

${ }^{54}$ Regina Grafe and María Alejandra Irigoin, "The Spanish Empire and its legacy: fiscal redistribution and political conflict in colonial and post-colonial Spanish America”, Journal of Global History 1, n. ${ }^{\circ} 2$ (2006): 241. John Muse-Fisher, "Financing a new nation: a comparative study of the financial roots of the USA and Gran Colombia”, Journal of Global History 7, n. ${ }^{\circ} 1$ (2012): 3.

55 Katharine Bjork, "The Link That Kept the Philippines Spanish: Mexican Merchant Interests and the Manila Trade, 1571-1815”, Journal of World History 9, n. ${ }^{\circ} 1$ (1998): 25.

${ }^{56}$ Edward R. Slack JR, "The Chinos in New Spain: A Corrective Lens for a Distorted Image”, Journal of World History 20, n. ${ }^{\circ} 1$ (2009): 35. Alejandra Irigoin, "The End of a Silver Era: The Consequences of the Breakdown of the Spanish Peso Standard in China and the United States, 1780s-1850s”, Journal of World History 20, n. ${ }^{\circ}$ 2 (2009): 207.
} 
regionalization, where networks and exchanges were denser, as happened in the Caribbean, which became a micro-space connected to several commercial circuits on a global scale ${ }^{57}$.

Fourth, Brown suggested as a temporary scenario a period ranging from 1830 to 1870 approximately $^{58}$; the predominance and diffusion on a planetary scale of what has been termed the Industrial Revolution, the impact of which is inscribed in the orbit of influence of a modern and global capitalism ${ }^{59}$. Likewise, this phenomenon illuminates the other side of the same coin by highlighting a kind of capitalism in Latin America that some scholars have traditionally referred to as embryonic or dependent ${ }^{60}$. One of the essential characteristics of this period was the emergence and subsequent consolidation of a labor system with free manpower as a counterpart to an old regime where there was a slave labor force or one that was conditioned to a specific institutional framework such as the Repartimiento and the Encomienda in the Latin American context. For the specific case of Brazil, the unilateral decision of the British Empire to adopt the free market in 1846 not only challenged its own labor system, but the repercussions of this were experienced on a planetary scale, forcing Brazil to suppress slave trade in 1850. This British resolution highlighted the obsolescence of slave trade and labor through the promotion of a free labor force. This also had an impact on productive systems such as that of sugar or contraband practices, which left a protectionist system behind to give way to free trade ${ }^{61}$.

This process as a whole left its mark on the transition towards the modernization of the different productive apparatuses and political systems as a key component of a worldwide manifestation. Furthermore, it interconnected with the emergence of certain analytical categories that made way for the citizen, the republic and democracy ${ }^{62}$. Regardless of the type of labor skills, such as unskilled workers native to India, China or other parts of Asia, known as coolies, or the skilled workers of American and European engineers who continually immigrated to Latin America as essential elements of the technological transfer, this new labor economy that was free in principle was transcendental in the transformation of the diverse productive apparatuses of the Americas ${ }^{63}$. This was accompanied by a process of expansion of international trade, which not only included the traditional merchandise of the $17^{\text {th }}$ and $18^{\text {th }}$ centuries, but also useful knowledge embodied in tangible technological products which were more systematically involved in exchanges, as well as the production of strategic raw materials (commodities) for industrial development that in turn

\footnotetext{
${ }^{57}$ Jeppe Mulich, "Microregionalism and intercolonial relations: the case of the Danish West Indies, 1730-1830", Journal of Global History 8, n. ${ }^{\circ} 1$ (2013): 72.

${ }^{58}$ Brown, "The global history of Latin America".

${ }^{59}$ Eric Hobsbawm, "First world and third world after the cold war". CEPAL Review, (1999): 8. Maxine Berg, "Technology, skills and the pre-modern economy in the East and the West by Maarten Prak and Jan Luiten van Zenden”, Journal of Global History 10, n. ${ }^{\circ} 3$ (2015): 505.

${ }^{60}$ Enrique Semo, Historia del capitalismo en México: Los orígenes: 1521/1763 (México: Era, 1973), 15. Celso Furtado, "El desarrollo desde el punto de vista interdisciplinario", El Trimestre Económico 46, n. ' 181 (1979): 5-33. Aníbal Quijano, Cuestiones y horizontes. De la dependencia histórico-estructural a la colonialidad/descolonialidad del poder (Buenos Aires: Colección Antologías-Consejo Latinoamericano de Ciencias Sociales, 2014), 85.

61 Tâmis Parron, "The British Empire and the Suppression of the Slave Trade to Brazil: A Global History Analysis", Journal of World History 29, n. ${ }^{\circ} 1$ (2018): 4-5.

62 James E. Sanders, “Atlantic Republicanism in Nineteenth-Century Colombia: Spanish America's Challenge to the Contours of Atlantic History", Journal of World History 20, n. ${ }^{\circ} 1$ (2009): 131.

${ }^{63}$ Steffen Rimmer, "Chinese abolitionism: the Chinese Education Mission in Connecticut, Cuba and Peru", Journal of Global History 11, n. ${ }^{\circ} 3$ (2016): 344. Matthew Pratt Guterl, "After Slavery: Asian Labor, the American South, and the Age of Emancipation”, Journal of World History 14, n. ${ }^{\circ} 2$ (2003): 209.
} 
interconnected continents. This was the case of copper that linked Latin America, Australia and South Africa in the same productive-commercial circuit ${ }^{64}$. This type of mercantile flow enabled an increase in the circulation of new knowledge and people despite the high costs they assumed from the point of view of adaptation to a relatively hostile environment ${ }^{65}$. The expansion of this industrial capitalism on a global scale had differentiated impacts in Latin America. On the one hand, it exerted pressure on the local productive apparatuses, while on the other hand, technology and the processes of technological change that were introduced had repercussions in traditional export activities, for example sugar in Cuba and in the West Indies, where invention and globalization were articulated ${ }^{66}$. These scenarios modified previously established knowledge and information networks. Another tangible manifestation derived from the same impulse was the consolidation of an elite group, typically of creole or European origin, that broadened its spectrum of social relationships beyond the limits imposed by the old colonial regimes, at the expense of increasing its dependence in general from both the technological and economic points of view ${ }^{67}$.

For the fifth and last period we have certain characteristics that show close continuity with what happened previously. Other phenomena appear, however, typical of the period of study, ranging from 1870 to 1920, marked by the rise of Western liberal capitalism and the crisis generated by the First World War. Regarding elements of continuity, the transnational circulation of European and North American engineers who worked in various Latin American and South African mines from the end of the $19^{\text {th }}$ century is outstanding. This mobility resulted in the construction of expert knowledge networks on a global scale, in this instance, associated with mining ${ }^{68}$.

Similarly, nationalist discourse expanded throughout much of the $19^{\text {th }}$ century as a phenomenon that was inherent in the configuration of the new countries, but as time went on this rhetoric took on clearer nuances with respect to the linkage of a space that went beyond the traditional borders that divided countries. An example of this was the nationalist discourse of José Martí that was not limited to Cuba alone, but rather included the right of national and personal self-determination as well as a sense of humanitarianism on a Latin American scale. This in turn particularized the process while interconnecting it with spatial scales of greater global dimensions, without abandoning a spectrum of universal values ${ }^{69}$. National values continued to spread until the first decades of the $20^{\text {th }}$ century, although they could manifest themselves in smaller spaces that were not any less important, linking them also to other factors such as race or ethnic group. In this last aspect, three empirical evidences of multiple spatial scales stand out. The first one is found in the social movement known as the "Negro

\footnotetext{
${ }^{64}$ Chris Evans and Olivia Saunders, "A world of copper: globalizing the industrial revolution, 1830-70", Journal of Global History 10, n. ${ }^{\circ} 1$ (2015): 3-26.

${ }^{65}$ Ralph Shlomowitz and Lance Brennan, "Epidemiology and Indian Migration at Home and Abroad", Journal of World History 5, n. ${ }^{\circ} 1$ (1994): 47, 49.

66 José Guadalupe Ortega, "Machines, modernity, and sugar: the Greater Caribbean in a global context, 181250”, Journal of Global History 9, n. ${ }^{\circ} 1$ (2014): 2.

${ }^{67}$ Jonathan Curry-Machado, "Rich flames and hires tears': sugar, sub-imperial agents and the Cuban phoenix of empire", Journal of Global History 4, n. ${ }^{\circ} 1$ (2009): 33.

${ }^{68}$ Stephen Tuffnell, "Engineering inter-imperialism: American miners and the transformation of global mining, 1871-1910”, Journal of Global History 10, n. ${ }^{\circ} 1$ (2015): 53.

${ }^{69}$ Armando García de La Torre, "The contradictions of late nineteenth-century nationalist doctrines: three keys to the 'globalism' of José Martí's nationalism”, Journal of Global History 3, n. ${ }^{\circ} 1$ (2008): 67.
} 
Renaissance" located in Harlem, New York ${ }^{70}$. It is feasible in turn to distinguish certain similar components expressed in other socio-historical contexts such as Mexico and Ireland, along the lines of an awakening of the national and the racial from a first post-war perspective globally. The second evidence is connected with the previous one through the exploitation of Japanese women by the imperial government that promoted their emigration to Brazil. In this case, imagery of a land full of natural resources and large spaces that could be used in strategic agricultural production for Japan's economy was promoted, a specific example being cotton production. This also offered an alternative to the racism that these Asian immigrants had suffered in the United States. This exploitation was part of the government's maneuver to influence a transnational space in accordance with expansionist interests in the inter-war period $^{71}$. Finally, other evidence distinct from the previous examples is presented in the Welsh settlement established in Patagonia called $Y$ Wladfa. This experience revealed the different forms of occupation of a space by a marginal and subordinate group in the context of the British Empire that managed to configure a physical and symbolic place to generate a new home, challenging these binary visions between the colonized and the colonizers right at the limit; it also set the tone for thinking about various forms of generating between-spaces in a world that is no longer conceived as dichotomous ${ }^{72}$.

Regarding the components, that are typical of the period but not disconnected from what has been pointed out so far, an incipient design of an international and institutional architecture stands out .Although it resulted in part from the rupture represented by the First World War, it also displayed remarkable continuity throughout the $20^{\text {th }}$ century, depending on what was inherited from the $19^{\text {th }}$ century.

One precursor of this was the organization of universal exhibitions where countries such as Brazil, Mexico and Peru participated on several occasions. These events constituted an ideal platform for participating in the mobility of people, objects and knowledge in general. Likewise, this made it possible for Latin American elites to exhibit articles or scientific-cultural products that were perceived as evidence that these nations were advancing in their respective modernization processes, in emulation of those in Europe or North America. If previously there had been an indigenist position to show its rejection of colonial powers (Portugal or Spain), the universal exhibitions of Paris (1889) and Chicago (1893) opened a window of opportunity for inserting themselves in a world where modernity prevailed $^{73}$. In this same context of international forums, although with a different nature, the momentum of the League of Nations at the end of the second decade of the twentieth century is outstanding, where certain Latin American countries also participated in discussions at that time through the International Federation of League of Nations Societies and the Federal Committee for European Cooperation. In this organizational framework, phenomena were

\footnotetext{
${ }^{70}$ Bob Johnson, “Globalizing the Harlem Renaissance: Irish, Mexican, and 'Negro' renaissances in The Survey, 1919-1929”, Journal of Global History 1, n. 2 (2006): 155.

${ }^{71}$ Sidney X. Lu, "Japanese American Migration and the Making of model Women for Japanese Expansion in Brazil and Manchuria, 1871-1945”, Journal of World History 28, n. ' 3 \& 4 (2017): 466.

72 Lucy Taylor, "Global perspective on Welsh Patagonia: the complexities of being both colonizer and colonized", Journal of Global History 13, n. ${ }^{\circ} 3$ (2018): 446-448.

73 Sven Schuster, "The world's fairs as spaces of global knowledge: Latin American archaeology and anthropology in the age of exhibitions", Journal of Global History 13, n. ${ }^{\circ} 1$ (2018): 70,74.
} 
woven together such as nationalism, imperialism, regionalism and a series of universal projects $^{74}$, typical of the spirit of the time.

\section{Other Interconnecting Events between Latin America and a Contemporary Global History}

Now, what is somewhat uncomfortable in this presentation of global historical times is that no reference is made to the $20^{\text {th }}$ century until about 1920 . In this time period, there are at least four events that overlap each other and that generate a contribution to the approach of interconnected history, where Latin America turns out to be a key actor, although not the only one ${ }^{75}$. The events we refer to are: the Second World War and the propagation of a Third World imaginary; the process of decolonization and the development of state economies, the rise of the Dependency Theory being of importance; the conflicts of the Cold War; and finally the rise of neoliberalism as a global strategy, economic in principle, but with an impact on broad spheres of Latin America and other parts of the world where the phenomenon was manifested, including former soviet type socialist countries in Central Europe. We will now explore each of these events in greater detail.

In the first place, we have World War II and the construction of a dominant imaginary where whole continents were reduced or homogenized around the hazy concept of Third World, a term originally proposed by Alfred Sauvy ${ }^{76}$. On the one hand, this set of nations can apparently be represented as passive victims of a sort, faced with the disputes of world powers over time ${ }^{77}$. The above is one of the typical perspectives of the postwar period and to some extent dichotomous, according to Mignolo's conception: First World-Third World, CenterPeriphery or East-West - resulting in a series of geo-historical categories, which at the limit have contributed to a supposed distribution of knowledge ${ }^{78}$ or an international division of the same, whose most palpable element would be the place that Spanish and Portuguese would occupy as marginal languages in these grand narratives of global history. However, the development of this imaginary attached to the confusing notion of the Third World, led to other movements grouped into the no less ambiguous name of Third Worldism. This concept is a representation in the margin of the way different peoples conceive of themselves on a global scale, which was gradually configured starting in the second half of the $20^{\text {th }}$ century and had feedback from various left-wing political tendencies, one of the main epicenters of

\footnotetext{
74 Anne-Isabelle Richard, "Competition and complementarity: civil society networks and the question of decentralizing the League of Nations", Journal of Global History 7, n. ${ }^{\circ} 2$ (2012): 223.

${ }^{75}$ For these events we have decided to leave classification by periods behind, because one of their characteristics is that they overlap each other; that is, they are interconnected through time and space in multiple ways. Therefore, making strict and arbitrary time periods is complicated, and it would contribute little to the approach we have proposed.

76 Alfred Sauvy, "Trois Mondes, Une planète”, L'Observateur, n. ${ }^{\circ} 118$ (1952).

77 Ananya Chakravarti, "Peripheral eyes: Brazilians and India, 1947-61”, Journal of Global History 10, n. ${ }^{\circ} 1$ (2015): 123. One of the emblematic works that contributed to projecting an image of victimization for Latin America, which to some extent coincides with the passivity imputed to the Dependency Theory by Carmagnani $(2004,14)$, as well as marking an entire generation and awakening the interest of many more at a global level, is the book The Open Veins of Latin America (1971) by Eduardo Galeano, which paradoxically can also be seen as a premonition of the times ahead for Latin America, especially after 1973. Eduardo Galeano, Las venas abiertas de América Latina (México: Siglo XXI, 2012).

${ }^{78}$ Mignolo, Historias locales/diseños globales...195, 345.
} 
which Christoph Kalter located in France ${ }^{79}$, its peak moment coming in May $1968^{80}$. A series of elegant euphemisms appeared independently of these two tendencies (victimization or revolutionary movements) according to Eric Hobsbawm ${ }^{81}$, and were added in order to describe the Third World in a more "neutral" manner, such as developing countries, less developed, poor, emerging, backward, etc. Seen critically, these terms have no other purpose than to avoid the term underdevelopment, understood not as a stage prior to development but rather as a historical-structural deficiency that is accompanied by a system of global domination that developed over centuries. Here we can highlight two important pioneers of studies on development, Raúl Prebisch and Gunnar Myrdal, each of whom contributed influential analyses in different institutional contexts, but which were interconnected through their theoretical conceptions of the problems of underdeveloped countries and their socioeconomic relationships in a global context ${ }^{82}$. To make this particular scenario of global history even more complex, it is feasible to add an urban hierarchization of the cities of the supposed and, in most cases, forgotten Second World, among which Budapest, Prague, Berlin or Moscow are listed, which in fact possess qualitative characteristics very similar to Vienna, Paris or London as first class urban centers.

A second event, which overlaps with the previous one, is the political and intellectual decolonization of the 1950s, the momentum of which lasted for more than two decades, based on a series of criticisms and initiatives that tended to question the structure of domination and control that resulted from the most recent international armed conflict. This scenario, immersed in the context of the first years of the Cold War, gave rise to new aspirations from a renewed national identity compatible with alternative movements such as Third Worldism, ecumenism or religious freedom that were embraced in Asia, Africa and Latin America. Likewise, these movements highlighted a socio-cultural differentiation from the periphery with respect to the $\mathrm{West}^{83}$. In the context of these movements it is feasible to cite the case of the World Council of Churches, which was a kind of Christian United Nations, that set the tone for organizing various religions in order to face the problems derived from Latin American authoritarianism, racism and global inequality by means of a Marxist and anticolonial discourse. The ecumenical movement emphasized its emancipation from the West and respect for human rights worldwide, which was incidental to feedback from the recent Universal Declaration of Human Rights promoted by the United Nations in 1948. One important element of this World Council of Churches was the criticism of religious Westernization, given the majority participation of European and North American churches. The most radical position of this Council was directed at the promotion of freedom of conscience, which in turn alluded to religious freedom. For Latin America, this call was reconfigured around liberation theology and the activism of Protestant religions that attained influence of global dimensions in the sixties. The key components of the ecumenical movement were the proposal of a social ethic based on human rights and a new

\footnotetext{
${ }^{79}$ Christoph Kalter, "From global to local and back: the 'Third World' concept and the new radical left in France", Journal of World History 12, n. ${ }^{\text {}} 1$ (2017): 116.

${ }^{80}$ Kristin Ross, Mai 68 et ses vie ultérieures (Paris: Agone, 2010), 132-133.

${ }^{81}$ Eric Hobsbawm, Sobre historia (Barcelona: Crítica-Grijalbo, 1998), 14-15.

82 Andrés Rivarola Puntigliano and Örjan Appelqvist, "Prebisch and Myrdal: development economics in the core and on the periphery", Journal of Global History 6, n. ${ }^{\circ} 1$ (2011): 29.

${ }^{83}$ Chakravarti, "Peripheral eyes: Brazilians and India, 1947-61”, 122.
} 
responsibility ${ }^{84}$. This global moment, marked by a time of profound transformations, was conducive to resonance with this and other international initiatives along similar lines, such as the case of the Non-Aligned countries, which sought to build a New International Economic Order and more equitably insert a group of nations that had been recognized as Second and Third Worlds since 1952.

In the specific case of Mexico, for example, an anthropological critique inspired by the Dependency Theory was carried out with certain "culturalist" analyzes ${ }^{85}$ (Rosemblatt, 2014, p. 94) which originated in the United States and Europe. The above was a clear manifestation against cultural imperialism, whose origins could well be traced back to the Enlightenment ${ }^{86}$. Another characteristic of this historical context was the active participation of the State through economic strategies tending to favor internal activity as a tool to reduce the politicaleconomic dependence inherent in any colonizing activity. Some evidence of these processes falls to the decolonization of the production of knowledge ${ }^{87}$ through the proliferation of postcolonial studies as an extension of their subaltern peers ${ }^{88}$; similarly, a more frequent use of specific vocabulary is highlighted, which although it is true that it was used more intensively between certain countries of the Maghreb, such as Algeria and France, this was extended to other nations classified in the diffuse group of the Third World. In other words, concepts such as discrimination, integration, gender and sexuality, human rights, religious freedom, etc., served to connect various social movements at a global level ${ }^{89}$; or in their absence, they manifested themselves as a continuity of the area of influence imposed by hegemonic systems and ideologies linked to gender, where the female body has been substantial in the construction of the modern State, even in small but significant peripheral countries like El Salvador, that in some way or another are interconnected with dynamics derived from the world system ${ }^{90}$. But state intervention also had concrete limits in its actions; some authors even consider them veritable collapses, such as those that occurred in fisheries in various parts of the globe, where a peculiar combination of factors of a local, environmental and worldwide nature became apparent. Among these experiences of collapse are the anchoveta breeding centers in Peru during the seventies. These breeding centers are nothing more than the manifestation of over-exploitation of natural resources and the inability of contemporary societies to adapt to the respective local ecological cycles. An

\footnotetext{
${ }^{84}$ Bastiaan Bouwman, "From religious freedom to social justice: the human rights engagement of the ecumenical movement from the 1940 to the 1970", Journal of Global History 13, n. ${ }^{\circ} 1$ (2018): $254-255$. Annegreth Schilling, "Between context and conflict: the 'boom' of Latin American Protestantism in the ecumenical movement (1955-75)”, Journal of Global History 13, n. ${ }^{\circ} 1$ (2018): 275-276.

85 Karin Alejandra Rosemblatt, "Modernization, dependency, and the global in Mexican critiques of anthropology", Journal of Global History 9, n. ${ }^{\circ} 1$ (2014): 94-121.

${ }^{86}$ Conrad, "Enlightenment in global history: A historiographical critique", 1005-1006.

${ }^{87}$ Schramm, "Estado, justicia y libertad. Aportes al pensamiento político desde Ditsö Káska y la diáspora africana", 37.

${ }^{88}$ Florencia E. Mallon, "The Promise and Dilema of Subaltern Studies: Prespectives from Latin American History", The American Historical Review 99, n. 5 (1994): 1491-1515.

${ }^{89}$ Todd Shepard, "Algeria, France, Mexico, UNESCO: a transnational history of antiracism and decolonization, 1932-1962”, Journal of Global History 6, n. ${ }^{\circ} 1$ (2011): 273. Ulrike Strasser and Heidi Tinsman, “It's a Man's World? World History Meets the History of Masculinity, in Latin American Studies, for Instance", Journal of World History 21, n. ${ }^{\circ} 1$ (2010): 75.

${ }^{90}$ Aldo V. García-Guevara, "Imperial detritus and the project of modernity: Sexuality, honor, and power in the bedroom and the courtroom in El Salvador, 1910-1960”, Journal of World History 28, n. ${ }^{\circ} 1$ (2017): 471-472.
} 
economic and political institutional design underlies these collapses, anchored to specific ideologies driven by the State ${ }^{91}$.

Furthermore, we find the maturation of the first formulations of an original and independent Latin American economic thought, credited fundamentally to the works of Raúl Prebisch $^{92}$ and Celso Furtado ${ }^{93}$, ideas that were later disseminated globally through the studies of the Economic Commission for Latin America and the Caribbean (ECLAC), as well as the Dependency Theory school of thought ${ }^{94}$. These perspectives were able to gain some followers in Asia, Africa and even in some Eastern European countries such as Romania ${ }^{95}$. To this set, which demonstrates the connectivity of Latin American activities with global events, are added educational projects that emerged in socialist countries but which are compatible with the spirit of the times, such as the case of the Cultural Revolution in China (1966-1976) and the Cuban Revolutionary Offensive (1968-1970), which, even though they were abandoned and considered to be historical failures ${ }^{96}$, it is no less true that there are some elements of connectivity with other events such as decolonization, the boom of state economies and the self-determination inherent in Third Worldism. Nevertheless, it is also important to highlight the appearance of a new sports-commercial imperialism, different from the imperialism described by V. I. Lenin where the protagonists were Nation-States 97. In this case protagonists did not necessarily come from a specific State, but rather from a group of States with a diversity of participation and fused by powerful commercial and communicative interests with a veritable planetary scope such as the Fédération Internationale de Football Association (FIFA) and the International Olympic Committee. FIFA particularly is a global organization par excellence in which the new forms of intervention of global capitalism, penetrating local scales, and the marked differences of sporting styles are manifest and concatenated in each of its international events, particularly

\footnotetext{
${ }^{91}$ Gregory Ferguson-Cradler, "Fisheries' collapse and the making of a global event, 1950s-1970s", Journal of Global History 13, n. ${ }^{\circ} 3$ (2018): 399-402.

92 Raúl Prebisch, "El desarrollo económico de la América Latina y algunos de sus principales problemas", El Trimestre Económico 63: n. ${ }^{\circ} 249$ (1996):175-245.

${ }^{93}$ Furtado, "El desarrollo desde el punto de vista interdisciplinario".

${ }^{94}$ Osvaldo Sunkel and Pedro Paz, El subdesarrollo latinoamericano y la teoría del desarrollo (México: Siglo XXI, 1991). Héctor Guillén Romo, "De la orden cepalina del desarrollo al neoestructuralismo en América Latina", Comercio Exterior 57, n. ${ }^{\circ} 4$ (2007): 295-313.

${ }^{95}$ Paul Dragos Aligica and Anthony Evans J, The neoliberal revolution in Eastern Europe. Economic ideas in the transition from communism (Cheltenham: Edward Elgar, 2009), 38. Joseph L. Love, Crafting the Third World. Theorizing Underdevelopment in Rumania and Brazil (California: Stanford University Press, 1996). For Romania, Love argues that the investigations of Mihail Manoilescu influenced Ibero-America since the 1930s and 1940s, especially with regard to the complications derived from the backwardness and dependence of Romania in terms of its economic relations with countries of Western Europe. Love, Crafting the Third World...,11-12. The propagation of Manoilescu's approach in Latin America overlaps with the gestation of the first intellectual conceptions of Raúl Prebisch, who would later express them in his article called: "El desarrollo económico de América Latina y algunos de sus principales problemas". Prebisch, "El desarrollo económico de la América Latina y algunos de sus principales problemas", [The economic development of Latin America and some of its main problems]. The configuration of this global context set the tone for the founding of ECLAC from which emanated an original interpretation of the economic challenges that Latin America faced and influenced the formation of several generations of specialists in development issues.

${ }^{96}$ Yinghong Cheng and Patrick Manning, "Revolution in Education: China and Cuba in Global Context, 195776", Journal of World History 14, n. ${ }^{\circ} 3$ (2003): 359.

${ }^{97}$ V.I. Lenin, "Una caricatura del marxismo y el 'economismo imperialista", in Obras completas (Madrid: Akal, 1977), 45.
} 
when the World Cup is celebrated ${ }^{98}$. In this last scenario Latin America contributes, in the broadest sense of the term, a fundamental role that goes beyond sports.

In the third place, we would like to propose as another key event the conflicts derived from the Cold War, which generated important dispute scenarios in Latin America, whose most emblematic cases were in Chile, Cuba and Nicaragua, in our opinion. Traditionally, this period, which runs from 1945 to 1989, is conceived as a bitter dispute between socioeconomic paradigms: on the one hand, Soviet-type socialism and on the other Western capitalism driven mainly by the United States ${ }^{99}$. It is worth remembering that the Soviet model being seen as the only viable socialism was questioned at various times in history. This was one of its main dilemmas from 1933 until practically the end of its days. We can find important scenarios from which these questions emerged and which in turn were raised as alternatives in the African National Congress in South Africa, Popular Unity in Chile and the Sandinista movements in Nicaragua ${ }^{100}$. Even Augusto César Sandino himself, between 1927 and 1929, thought about building a democratic socialism outside the imaginary imposed by the Soviet Union and by a series of communist parties scattered throughout the world that also included the Mexican Communist Party ${ }^{101}$. This was the reason for his personal break with the Communist International and the withdrawal of its institutional support, which closed the way to democratic socialist demonstrations as well as to the same social democracy in Nicaragua and other parts of the globe. Therefore, an inherent characteristic of the crisis derived from the Cold War was that, once again, countries of the so-called Third World were the backdrop. Nevertheless, there are other elements that are equally important for global history, such as the attractiveness of the Soviet industrialization model accompanied by an educational strategy for the masses. Its rapid results attracted attention in countries such as Brazil during the 1950 s to such a degree that this phenomenon was considered "socialist modernity"102, capable of imitating and challenging Western styled capitalist modernity.

Furthermore, essential symbolisms emerged that marked the political battles beyond the Cold War period, such as the figure of Ernesto "El Che" Guevara or the feminist movements that gradually became radicalized and served as a prelude to broader human rights initiatives ${ }^{103}$. As for "El Che" Guevara, his image is part of a political iconography of the revolution and solidarity among Third World countries. Additionally, it was not only interconnected with the movements of these nations, but has also impacted other political

\footnotetext{
98 Paul Dietschy, "Making football global? FIFA, Europe, and the non-European football world, 1912-74", Journal of Global History 8, n. ${ }^{\circ} 2$ (2013): 279.

99 James F. Rochlin, "Who said the Cold War is over? The political economy of strategic conflict between Venezuela and Colombia", Third World Quarterly 32, n. ${ }^{\circ} 2$ (2001): 240. Daniel Berger et al., "Commercial imperialism? Political influence and trade during the Cold War”, American Economic Review 103, n. ${ }^{\circ} 3$ (2013): 864. Michael Cox, "Fred Halliday, Marxism and the Cold War", International Affairs 85, n. ${ }^{\circ} 5$ (2011): 1109. Adam Piette, "Writing into the Cold War West", Theory, Culture \& Society 28, n. ' 7-8 (2011): 392. Paul Rogers, "A century of the edge: from Cold War to hot world, 1945-2045”, International Affairs 90, n. ${ }^{\circ} 1$ (2014): 94.

100 William Smaldone, "Socialist Paths in a Capitalist Conundrum: Reconsidering the German Catastrophe of 1933". Journal of World History 18, n. ${ }^{\text {o }} 3$ (2007): 297.

${ }^{101}$ Alejandro Bendaña, Sandino. Patria y libertad (Managua: Anamama, 2016), 383.

102 Tobias Rupprecht, "Socialist high modernity and global assignation: a shared history of Brazil and the Soviet Union during the Cold War", Journal of Global History 6, n. ${ }^{\circ} 3$ (2011): 505.

103 Judith P Zinsser, "From Mexico to Copenhagen to Nairobi: The United Nations Decade for Women, 19751985”, Journal of World History 13, n. ${ }^{\circ} 1$ (2002): 139.
} 
initiatives ${ }^{104}$, including those of the Western capitalist powers. A counter strategy was created after the "Che" experience in Bolivia that has tried to minimize its symbolic-ideological influence, but it has proven difficult to achieve that goal, to speak of progressist movements without the figure of Ernesto Guevara appearing at a certain time as a synonym for revolution in a global context is complicated. To this set of elements, we add one of a geographical nature, the role played by human settlements located in rural areas known generically as towns or villages. Many of the conflicts of the Cold War period developed around this type of locality where the inhabitants, a high proportion of which were peasants, fought in the insurgency and counterinsurgency movements; only a few battles took place in big cities. As a general rule, the main scenario of dispute for a conflict of global dimensions was the rural environment of towns or villages ${ }^{105}$. Austere rural and, in turn militarized panoramas, synonymous with struggle in the Third World, are some of the most pervasive symbols of these crises in the framework of the Cold War. Finally, we would like to emphasize the importance of the invasion of Afghanistan, which began in 1979, for the historical trajectory of the Soviet Union. Once the Soviet type socialist systems fell, a considerable proportion of the nations that intervened in these military movements with varying intensities chose to make radical changes in terms of the role they played within these tensions at a global level $^{106}$. One of the most significant examples in this sense was South Africa and the disappearance of Apartheid ${ }^{107}$.

The fourth and last event, which strictly speaking we might call a set of events, at the center of which is the unprecedented progress of neoliberalisations, is framed in a global context par excellence, where the concomitant rise of English as lingua franca is added ${ }^{108}$. The manifestation of this set of phenomena acquired remarkable importance, beginning with the fall of the Berlin Wall in the autumn of 1989 and the consequent disappearance of Soviettype socialist systems in Central Europe; events that resulted in a greater visualization of the interconnections and simultaneities between westernization, globalization, miscegenation or the promotion of a specific "civilization" (the civilization of the free market) as something desirable or as an achievement to be attained ${ }^{109}$.

This type of commodification penetrated various aspects of daily life. In particular, we can point out the commercialization of all kinds of knowledge, for example herbal and traditional medicine. In the case of Paraguay, its popular natural sweetener was transformed into a well-known brand of low-calorie sweeteners with a celebrated reputation in the world market. Consumers recognize this product by the name of Stevia with advertising that alludes

\footnotetext{
104 Jeremy Prestholdt, "Resurrecting Che: radicalism, the transnational imagination, and the politics of heroes", Journal of Global History 7, n. ${ }^{\circ} 3$ (2012): 506.

105 Nicole Sackley, “The village as Cold War site: experts, development, and the history of rural reconstruction", Journal of Global History 6, n. ${ }^{\circ} 3$ (2011): 481.

106 Jarle Simensen, «Democracy and globalization: Nineteen eighty-nine and the "Third Wave" », Journal of World History 10, n. ${ }^{\circ} 2$ (1999): 395.

${ }^{107}$ George Lawson, Negotiated Revolutions. The Czech Republic, South Africa and Chile (Aldershot: Ashgate, 2005), 121.

108 David Harvey, A brief history of neoliberalism (Oxford: Oxford University Press, 2005), 13. Serge Audier, Néo-libéralisme(s). Une archéologie intellectuelle (Paris: Bernard Grasset, 2012), 475. Anderson, Perry. El nuevo viejo mundo. Madrid: Akal, 2012, 161.

${ }^{109}$ Serge Gruzinski, Les quatre parties du monde. Histoire d'une mondialisation (Paris: La Martinière, 2004), 399. Mignolo, Historias locales/diseños globales..., 355.
} 
to how the Guaraní people have used it as a kind of sweetener for centuries ${ }^{110}$. Interdependence was heightened in this peculiar international scenario due to a variety of metaphors that have been extracted from certain notions of progress and development, where the common denominator among them was the resurgence of growth without limits or of growth at all costs as an inexorable element in this phase of the global capitalist system ${ }^{111}$. To this must be added the processes of democratization as an inherent component of the institutional change of the late $20^{\text {th }}$ century with its most varied results. From this perspective, Latin America has been seen as a continent with a long authoritarian tradition, susceptible to being transformed through the influence of interconnection with global events ${ }^{112}$. One substantiation in this sense came about after the coup d'état on September 11, 1973 in Chile and the consequent repression that was unleashed, to such a degree that it awakened global interest in human rights which was intertwined with other socio-political movements that developed in different parts of the planet. In other words, the demands for respect of human rights in Chile during the dictatorship of Augusto Pinochet were not isolated petitions at all, nor were they particular cases with regard to what was happening in other parts of the planet; instead, they were part of an intricate history with global implications ${ }^{113}$.

\section{Conclusions}

To conclude, we would like to point out that, together with the intensification of the Western-style modernization process on a global scale, some contradictions have been manifested that have jeopardized the success of this project of institutional change. Importantly among these, is the questioning of a vision that conceives of Europe as the birthplace of the modern world or an alleged European universality ${ }^{114}$, while the colonies or former colonies would be pre-modern societies by definition. Likewise, this strategy is presented as inevitable in a techno-evolutionary configuration, which in turn supposedly leads to the advancement of one type of civilization that is adaptable to any historical context despite the diversity inherent in Europe and the environmental degradation that this adaptability entails ${ }^{115}$. Precisely, this questioning became more relevant in East Asia beginning with the last quarter of the $20^{\text {th }}$ century, because that was where this new way of conceiving the productive world ${ }^{116}$ was adapted best. This was the case to such an extent that China with its communist political system displaced Europe as one of the main centers of

${ }^{110}$ María Chesterton and Timothy Yang, «The Global Origins of a "Paraguayan" Sweetener: Ka'a He’e and Stevia in the Twentieth Century», Journal of World History 27, n. ${ }^{\circ} 2$ (2016): 255.

${ }^{111}$ M. Prak, "The Cambridge history of capitalism Vol.1 The rise of capitalism: from ancient origins to 1848; vol. 2: The spread of capitalism: from 1848 to the present by Larry Neal and Jeffrey G. Williamson", Journal of Global History 10, n. ${ }^{\circ} 3$ (2015): 506. Eduardo Gudynas, Ecología, economía y ética del desarrollo sostenible (Costa Rica: Coscoroba Ediciones-UNED, 2002).

112 Simensen, «Democracy and globalization: Nineteen eighty-nine and the "Third Wave" ", 391, 393, 394, 409.

113 Patrick William Kelly, "The 1973 Chilean coup and the origins of transnational human rights activism", Journal of Global History 8, n. ${ }^{\circ} 1$ (2013): 165.

${ }^{114}$ Marcello Carmagnani, El otro occidente. América Latina desde la invasión europea hasta la globalización (Mexico: FCE, 2004), 19.

115 Conrad, "Enlightenment in global history: A historiographical critique", 999, 1019. Daniel Cohen, Richesse du monde pauvretés des nations (Paris: Flammarion, 1997), 45. Hobsbawm, Sobre historia ...,228. Julia Moses y Martin Dauton, "Editorial- border crossing: global dynamics of social policies and problems", Journal of Global History 9, n. ${ }^{\circ} 2$ (2014): 181.

${ }^{116}$ David Harvey, El enigma del capital y las crisis del capitalismo (Madrid: Akal, 2012), 177. 
economic-global influence ${ }^{117}$, a situation that will probably repeat itself in the not too distant future with the United States, which would open the door to a reinterpretation of global history ${ }^{118}$, or to a new global history whose essential characteristic would be the illumination of new areas of interest, such as Latin America, in a context of multiple modernizations where Europe in particular and the West in general will surely be certain cases among many other experiences that can be interconnected over time in a historical narrative with a truly global scope.

Specifically as regards Latin America, when it is addressed as an object of study in the articles published in the Journal of World History, over time it has not only been neglected or peripheralized, but references to this continent have also been concentrated in certain historical periods, where analytical gaps in other time periods are evident or, failing that, in the events we have pointed out. The historical period in which this scientific journal concentrated works on Latin America the majority of the main subject matter has been of the second half of the $16^{\text {th }}$ century and the $17^{\text {th }}$ century, a period of time that was marked by the influence of the Atlantic world through the rise of slave economies and global trade. In the second instance there is the Discovery by the Europeans and the Conquest of the Americas around 1500. Later on, there is the late colonial period, the institutional crises of the colonial order and the processes of independence that cover the eighteenth and nineteenth centuries. Other periods have been covered intermittently, as we can see in the sorting of collaborations in Table 1, although there are articles that cover the period of the Second World War and the construction of a Third World imaginary. It is clear how the first centuries of the history of Latin America have been privileged, according to time periods proposed fundamentally from the West. In the corresponding concentration map (Table 2), this situation is more than evident.

Regarding the Journal of Global History, as had been anticipated, the appearance of Latin America as a main object of study has shown a better distribution over time. In this case, the years that cover the emergence of liberal capitalism (circa 1870), the First World War until 1920, stand out as the main period of study. Secondly, we have the events surrounding Decolonization, the global advent of state economies, as well as the rise of the Dependency Theory, facts chronicled after the Second World War. Third, but not far from what has been published in other periods (Table 1), is the stretch of time that takes into consideration the Influence of the Atlantic World through the slave economies and global trade that date from the second half of the $16^{\text {th }}$ century and the $17^{\text {th }}$ century. On the respective concentration map (Table 3), it is clear how better temporal distribution of the topics of study on Latin America is achieved as of 2011, because in the first years of publication (20062010), the key events that cover practically the entire $20^{\text {th }}$ century and part of the $21^{\text {st }}$ century are conspicuous for their absence as topics of interest in the articles published in the Journal of Global History.

\footnotetext{
117 In March of 1979, once it was decided in China to push economic reforms, an optimistic analysis of The Economist mentioned that by 1990 the Chinese economy would be a medium-sized exporter for international trade, handling figures similar to those of Great Britain, but it seemed difficult for the objectives to be reached by 1985 according to the calculations of the Chinese government, which foresaw an average annual economic growth of $7 \%$. Years later, we have seen how China exceeded all economic expectations, even the most generous predictions (“How much can China export?", The Economist, 03/03/1979, p.63. Issue 7070).

${ }^{118}$ Lou Xu, "Reconstructing world history in the People's Republic of China since the 1980s", Journal of World History 18, n. ${ }^{\text {o }} 3$ (2007): 339.
} 
The peripheralization of Latin America in the main narratives of the global past represents a challenge as well as an opportunity for historians inspired by Latin America and interested in contributing with this methodological approach. The perspective proposed here could contribute to building a new global history with, we suggest, a more global approach, as a recent publication suggested in its title ${ }^{119}$. Even though, generally speaking, this paradoxical practice of global history also tends to be accentuated in the first lustrums of the 21 st century.

Indeed, many of the articles cited in this essay also refer in varying degrees to this paradox. In other words, the issue is not completely ignored in the journals analyzed here, but neither does it dominate the respective editorial lines. For our part, we would like to emphasize how the events associated with the neoliberalization process, which from a global perspective can broadly range from 1979 to 2000 (without neglecting the particular case of Chile that could well cover the period up to 1973), have not been systematically studied in any of the two journals we have analyzed in this essay. Therefore, we detect a valuable opportunity to study the role played by Latin America in this phenomenon over time, which interconnects with other very different spaces in terms of historical trajectory, as has been the case in Central Europe.

\footnotetext{
${ }^{119}$ Sven Beckert and Dominic Sachsenmaier, eds., Global history, globally: research and practice around the world (London-New York: Bloomsbury Academic), 2018.
} 
Table 1. Periods and events on Global History under a Latin American approach: Journal of World History (1990-2017) and Journal of Global History (2006-2018-I).

\begin{tabular}{|c|c|c|c|c|c|c|c|c|}
\hline \multicolumn{5}{|c|}{ Brown's periods (2015) } & \multicolumn{4}{|c|}{ Key events during the $20^{\text {th }}$ and $21^{\text {st }}$ centuries } \\
\hline \begin{tabular}{|l|} 
I. Discovery \\
and \\
Conquest \\
around 1500
\end{tabular} & \begin{tabular}{|l|} 
II. Atlantic \\
World \\
Influence: \\
slave \\
economies \\
and global \\
commerce \\
second half of \\
$16^{\text {th }}$ and all of \\
$17^{\text {th }}$ century \\
\end{tabular} & $\begin{array}{|lr|}\text { III. } & \text { Late } \\
\text { Colonial } & \\
\text { period, and } \\
\text { Independence } \\
\text { Crisis, late } \\
18^{\text {th }} \text { and early } \\
19^{\text {th }} \text { centuries }\end{array}$ & \begin{tabular}{|l|} 
IV. \\
Industrial \\
Revolution \\
circa 1830- \\
1870
\end{tabular} & \begin{tabular}{|l} 
V. Liberal \\
Capitalism, \\
1870, I \\
World War \\
until 1920
\end{tabular} & \begin{tabular}{|lr} 
VI. II & World \\
War & and \\
Thirdworldist \\
imaginary
\end{tabular} & \begin{tabular}{|l|} 
VII. \\
Decolonization, \\
State \\
Economies and \\
the diffusion of \\
Dependence \\
Theory
\end{tabular} & $\begin{array}{l}\text { VIII. Cold } \\
\text { War } \\
\text { Conflicts }\end{array}$ & $\begin{array}{l}\text { IX. } \\
\text { Neoliberalizations }\end{array}$ \\
\hline $\begin{array}{l}\text { Muldoon } \\
(1991)\end{array}$ & Alden (1992) & $\begin{array}{l}\text { Thornton } \\
(1993)\end{array}$ & \begin{tabular}{|l|} 
Shlomowit \\
and Brennan \\
$(1994)$
\end{tabular} & $\begin{array}{l}\text { Johnson } \\
(2006)\end{array}$ & $\begin{array}{l}\text { Rivarola } \\
\text { Puntigliano } \\
\text { and } \\
\text { Appelqvist } \\
(2011) \\
\end{array}$ & $\begin{array}{l}\text { Cheng and } \\
\text { Manning } \\
(2003)\end{array}$ & $\begin{array}{l}\text { Zinsser } \\
(2002)\end{array}$ & Kelly (2013) \\
\hline $\begin{array}{l}\text { Crosby } \\
(1991)\end{array}$ & $\begin{array}{l}\text { Palmer } \\
(1995)\end{array}$ & Bjork (1998) & $\begin{array}{l}\text { Guterl } \\
(2003)\end{array}$ & $\begin{array}{l}\text { García de la } \\
\text { Torre (2008) }\end{array}$ & Kalter (2017) & $\begin{array}{lr}\text { Strasser } & \text { and } \\
\text { Tinsman }(2010)\end{array}$ & $\begin{array}{l}\text { Smaldone } \\
(2007)\end{array}$ & $\begin{array}{l}\text { Chesterton and } \\
\text { Yang (2016) }\end{array}$ \\
\hline $\begin{array}{l}\text { Phillips } \\
\text { (1992) }\end{array}$ & $\begin{array}{l}\text { Thompson } \\
(1999)\end{array}$ & Curtin (1999) & \begin{tabular}{|l} 
Curry- \\
Machado \\
$(2006)$ \\
\end{tabular} & $\begin{array}{l}\text { Richard } \\
(2012)\end{array}$ & $\begin{array}{l}\text { Chakravati } \\
(2015)\end{array}$ & Shepard (2011) & $\begin{array}{l}\text { Sackley } \\
(2011)\end{array}$ & \\
\hline $\begin{array}{l}\text { Karttunen } \\
\text { (1992) }\end{array}$ & $\begin{array}{l}\text { Benton } \\
(2000)\end{array}$ & Drake (2004) & $\begin{array}{l}\text { Sanders } \\
(2009)\end{array}$ & $\begin{array}{l}\text { Tuffnell } \\
(2015)\end{array}$ & & $\begin{array}{l}\text { Dietschy } \\
(2013)\end{array}$ & $\begin{array}{l}\text { Rupprecht } \\
\text { (2011) }\end{array}$ & \\
\hline $\begin{array}{l}\text { Finlay } \\
(2004)\end{array}$ & $\begin{array}{l}\text { Martel } \\
(2006)\end{array}$ & $\begin{array}{l}\text { Grafe and } \\
\text { Irigoin (2006) }\end{array}$ & $\begin{array}{l}\text { Ortega } \\
(2014)\end{array}$ & $\begin{array}{l}\text { Brown } \\
(2015)\end{array}$ & & $\begin{array}{l}\text { Rosemblatt } \\
\text { (2014) }\end{array}$ & $\begin{array}{l}\text { Prestholdt } \\
\text { (2012) }\end{array}$ & \\
\hline
\end{tabular}




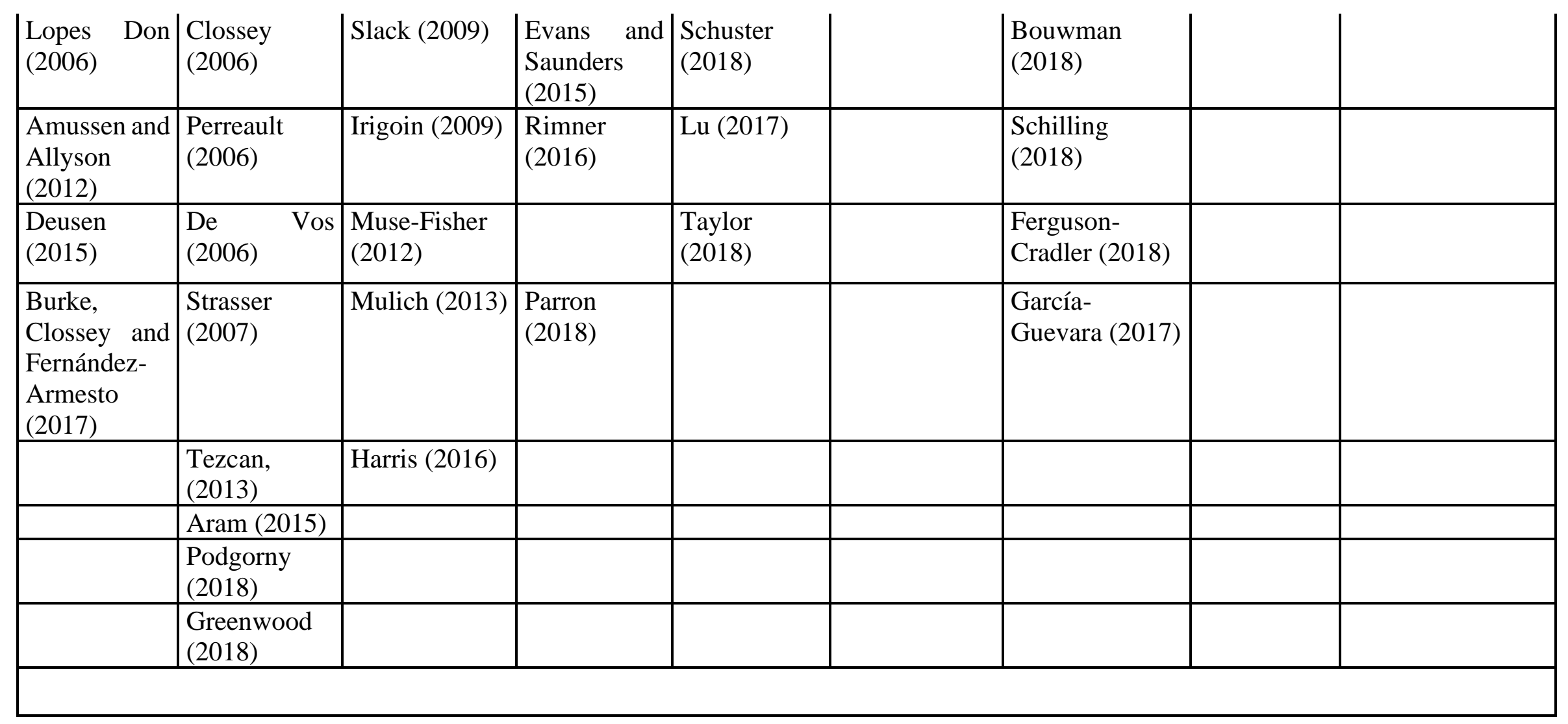

Source: Own elaboration based on Journal of World History (1990-2018) and Journal of Global History (2006-2018-I). 
Table 2. Concentration Map. Global History's periods and key events in Journal of World History.

\begin{tabular}{|c|c|c|c|c|c|c|c|c|}
\hline & \multicolumn{4}{|c|}{$\begin{array}{c}\text { Brown's } \\
\text { Periods (2015) }\end{array}$} & \multicolumn{4}{|c|}{$\begin{array}{l}\text { Key events } \\
\text { during the 20th } \\
\text { and 21th } \\
\text { Centuries }\end{array}$} \\
\hline & \begin{tabular}{|l|l}
$\mathrm{I}$ & $\mathrm{II}$ \\
\end{tabular} & III & IV & $\mathrm{V}$ & $\mathrm{VI}$ & VII & VIII & IX \\
\hline & & & & & & & & \\
\hline 1990 & & & & & & & & \\
\hline 1991 & & & & & & & & \\
\hline 1992 & & & & & & & & \\
\hline 1993 & & & & & & & & \\
\hline 1994 & & & & & & & & \\
\hline 1995 & & & & & & & & \\
\hline 1996 & & & & & & & & \\
\hline 1997 & & & & & & & & \\
\hline 1998 & & & & & & & & \\
\hline 1999 & & & & & & & & \\
\hline 2000 & & & & & & & & \\
\hline 2001 & & & & & & & & \\
\hline 2002 & & & & & & & & \\
\hline 2003 & & & & & & & & \\
\hline 2004 & & & & & & & & \\
\hline 2005 & & & & & & & & \\
\hline 2006 & & & & & & & & \\
\hline 2007 & & & & & & & & \\
\hline 2008 & & & & & & & & \\
\hline 2009 & & & & & & & & \\
\hline 2010 & & & & & & & & \\
\hline 2011 & & & & & & & & \\
\hline 2012 & & & & & & & & \\
\hline 2013 & & & & & & & & \\
\hline 2014 & & & & & & & & \\
\hline 2015 & & & & & & & & \\
\hline 2016 & & & & & & & & \\
\hline 2017 & & & & & & & & \\
\hline 2018 & & & & & & & & \\
\hline
\end{tabular}

\begin{tabular}{|c|}
\hline Simbology \\
\hline 1 article \\
\hline 2 articles \\
\hline
\end{tabular}

Source: Own elaboration based on Journal of World History (1990-2018-I). 
Table 3. Concentration Map. Global History's periods and key events in Journal of Global History.

\begin{tabular}{|c|c|c|c|c|c|c|c|c|c|}
\hline & \multicolumn{5}{|c|}{$\begin{array}{c}\text { Brown's Periods } \\
\qquad(2015)\end{array}$} & \multicolumn{4}{|c|}{$\begin{array}{c}\text { Key events during } \\
\text { the 20th and 21th } \\
\text { Centuries }\end{array}$} \\
\hline & I & II & III & IV & $\mathrm{V}$ & VI & VII & VIII & IX \\
\hline 2006 & & & & & & & & & \\
\hline 2007 & & & & & & & & & \\
\hline 2008 & & & & & & & & & \\
\hline 2009 & & & & & & & & & \\
\hline 2010 & & & & & & & & & \\
\hline 2011 & & & & & & & & & \\
\hline 2012 & & & & & & & & & \\
\hline 2013 & & & & & & & & & \\
\hline 2014 & & & & & & & & & \\
\hline 2015 & & & & & & & & & \\
\hline 2016 & & & & & & & & & \\
\hline 2017 & & & & & & & & & \\
\hline 2018 & & & & & & & & & \\
\hline
\end{tabular}

\begin{tabular}{|c|c|}
\hline \multicolumn{2}{|c|}{ Simbology } \\
\hline & 1 article \\
\hline 2 articles \\
\hline 3 articles \\
\hline
\end{tabular}

Source: Own elaboration based on Journal of Global History (2006-2018). 


\section{Bibliography}

Alden, Dauril. "Changing Jesuits Perception of the Brasis During the Sixteenth Century". Journal of World History 3, n. ${ }^{\circ} 2$ (1992): 205-218.

Aligica, Paul Dragos and Anthony Evans J. The neoliberal revolution in Eastern Europe. Economic ideas in the transition from communism. Cheltenham: Edward Elgar, 2009.

Amussen, Susan D. and Allyson M. Poska. "Restoring Miranda: gender and the limits of European patriarchy in the early modern Atlantic world". Journal of Global History 7 , n. ${ }^{\circ} 3$ (2012): 342-363.

Anderson, Perry. El nuevo viejo mundo. Madrid: Akal, 2012.

Aram, Bethany. "Caribbean ginger and Atlantic trade, 1570-1648". Journal of Global History 10, n. ${ }^{\circ} 3$ (2015):410-430.

Audier, Serge. Néo-libéralisme(s). Une archéologie intellectuelle. Paris: Bernard Grasset, 2012.

Bayly, C.A. La naissance du monde moderne. Paris: Editions de l'Atelier/ Éditions Ouvrières, 2007.

Beckert, Sven and Dominic Sachsenmaier, eds. Global history, globally: research and practice around the world. London-New York: Bloomsbury Academic, 2018.

Bendaña, Alejandro. Sandino. Patria y libertad, Managua: Anamama, 2016.

Bentley, Jerry H. "The Journal of World History". In Global Practice in World History. Advances Worldwide, edited by Patrick Manning, 129-140. Princeton: Markus Wiener Publisher, 2008.

Benton, Lauren A. "The Legal Regime of the South Atlantic World, 1400-1750: Jurisdictional Complexity as Institutional Order". Journal of World History 11, n. ${ }^{\circ} 1$ (2000): 27-56.

Berg, Maxine. "Technology, skills and the pre-modern economy in the East and the West by Maarten Prak and Jan Luiten van Zenden”. Journal of Global History 10, n. ${ }^{\circ} 3$ (2015): 504-506.

Berger, Daniel, William Easterly, Nathan Nunn, and Shanker Satyanath. "Commercial imperialism? Political influence and trade during the Cold War". American Economic Review 103, n. ${ }^{\circ} 3$ (2013): 863-896.

Bihr, Alain. "Oú est née la mondialisation? 'Histoire globale' berceau occidental”. Le Monde Diplomatique, Septembre 2018. Consulted Septembre 24th 2018. https://www.monde-diplomatique.fr/2018/09/BIHR/59013. 2018. 
Bjork, Katharine. "The Link That Kept the Philippines Spanish: Mexican Merchant Interests and the Manila Trade, 1571-1815”. Journal of World History 9, n. ${ }^{\circ} 1$ (1998): 25-50.

Bouwman, Bastiaan. "From religious freedom to social justice: the human rights engagement of the ecumenical movement from the 1940 to the 1970". Journal of Global History 13, n. ${ }^{\circ} 1$ (2018): 252-273.

Braudel, Fernand. La dynamique du capitalisme. Paris: Champs-Flammarion, 1985.

Brown, Matthew. "The global history of Latin America". Journal of Global History 10, n. ${ }^{\circ}$ 3 (2015): 365-386.

Burke, Peter, Luke Clossey and Felipe Fernández-Armesto. "The global Renaissance". Journal of World History 28, n. ${ }^{\circ} 1$ (2017): 1-30.

Carmagnani, Marcello. El otro occidente. América Latina desde la invasión europea hasta la globalización. Mexico: FCE, 2004.

Cervera, José Antonio and Ricardo Martínez Esquivel. "Puebla de los Ángeles, entre China y Europa. Palafox en las controversias de los ritos chinos”. Historia Mexicana 68, n. ${ }^{\circ}$ 1 (2018):245-284.

Chakravarti, Ananya, "Peripheral eyes: Brazilians and India, 1947-61". Journal of Global History 10, n. ${ }^{\circ} 1$ (2015): 122-146.

Cheng, Yinghong and Patrick Manning. "Revolution in Education: China and Cuba in Global Context, 1957-76". Journal of World History 14, n. ${ }^{\circ} 3$ (2003): 359-391.

Chesterton, María and Timothy Yang. «The Global Origins of a "Paraguayan" Sweetener: Ka'a He'e and Stevia in the Twentieth Century». Journal of World History 27, n. ${ }^{\circ} 2$ (2016): 255-279.

Clossey, Luke. "Merchants, migrants, missionaries, and globalization in the early-modern Pacific”. Journal of Global History 1, n. ${ }^{\circ} 1$ (2006) : 41-58.

Cohen, Daniel. Richesse du monde pauvretés des nations, Paris : Flammarion, 1997.

Conrad, Sebastian. "Enlightenment in global history: A historiographical critique". American Historical Review 117, n. ${ }^{\circ} 4$ (2012): 999-1027.

Cox, Michael. "Fred Halliday, Marxism and the Cold War". International Affairs 85, n. ${ }^{\circ} 5$ (2011): 1107-1122.

Crosby, Alfred W. "Infectious Disease and the Demography of the Atlantic". Journal of World History 2, n. ${ }^{\circ} 2$ (1991):119-133. 
Curry-Machado, Jonathan. "“Rich flames and hires tears': sugar, sub-imperial agents and the Cuban phoenix of empire”. Journal of Global History 4, n. ${ }^{\circ} 1$ (2009): 33-56.

Curtin, Philip D. "Location in History: Argentina and South Africa in the Nineteenth Century". Journal of World History 10, n. ${ }^{\circ} 1$ (1999): 41-92.

De Vos, Paula Susan. "The Science of Spices: Empiricism and Economic Botany in the Early Spanish Empire”. Journal of World History 17, n. ${ }^{\circ} 4$ (2066): 399-417.

De Vries, Jan. "The industrial revolution and the industrious revolution". Journal of Economic History 54, n. ${ }^{\circ} 2$ (1994): 249-270.

Dietschy, Paul. "Making football global? FIFA, Europe, and the non-European football world, 1912-74". Journal of Global History 8, n. ${ }^{\circ} 2$ (2013): 279-298.

Drake, James David. "Appropriating a Continent: Geographical Categories, Scientific Metaphors, and the Construction of Nationalism in British North America and Mexico". Journal of World History 15, n. ${ }^{\circ} 3$ (2004): 323-357.

Enrigue, Álvaro. "The curse of Cortés". The New York Review of Books, May 24 2018. Consulted May 25th 2018. https://www.nybooks.com/articles/2018/05/24/mexicocurse-of-cortes.

Evans, Chris and Olivia Saunders. "A world of copper: globalizing the industrial revolution, 1830-70”. Journal of Global History 10, n. ${ }^{\circ} 1$ (2015): 3-26.

Ferguson-Cradler, Gregory. "Fisheries' collapse and the making of a global event, 1950s1970s". Journal of Global History 13, n. ${ }^{\circ} 3$ (2018): 399-424.

Ferrer, Aldo. Historia de la globalización. Orígenes del orden económico mundial. México: FCE, 1996.

Finlay, Robert. "How Not to (Re) Write History: Gavin Menzies and the Chinese Discovery of America". Journal of World History 15, n. ${ }^{\circ} 2$ (2004): 229-242.

Furtado, Celso. "El desarrollo desde el punto de vista interdisciplinario". El Trimestre Económico 46, n. ${ }^{\circ} 181$ (1979): 5-34.

Galeano, Eduardo. Las venas abiertas de América Latina. México: Siglo XXI, 2012.

García de La Torre, Armando. "The contradictions of late nineteenth-century nationalist doctrines: three keys to the 'globalism' of José Martí's nationalism". Journal of Global History 3, n. ${ }^{\circ} 1$ (2008): 67-88.

García-Guevara, Aldo V. "Imperial detritus and the project of modernity: Sexuality, honor, and power in the bedroom and the courtroom in El Salvador, 1910-1960". Journal of World History 28, n. ${ }^{\circ} 1$ (2017): 469-492. 
Gobat, Michel. "The Invention of Latin America: A Transnational History of AntiImperialism, Democracy, and Race". The American Historical Review 18, n. 5 (2013): 1345-1375.

Grafe, Regina and María Alejandra Irigoin. "The Spanish Empire and its legacy: fiscal redistribution and political conflict in colonial and post-colonial Spanish America". Journal of Global History 1, n. ${ }^{\circ} 2$ (2006): 241-267.

Greenwood, Jonathan. "Readable flowers: global circulation and translation of collected saints' lives". Journal of Global History 13, n. ${ }^{\circ} 1$ (2018): 22-45.

Gruzinski, Serge. Les quatre parties du monde. Histoire d'une mondialisation. Paris: La Martinière, 2004.

Gudynas, Eduardo. Ecología, economía y ética del desarrollo sostenible. Costa Rica: Coscoroba Ediciones-UNED, 2002.

Guillén Romo, Héctor. "De la orden cepalina del desarrollo al neoestructuralismo en América Latina”. Comercio Exterior 57, n. ${ }^{\circ} 4$ (2007): 295-313.

Guterl, Matthew Pratt. "After Slavery: Asian Labor, the American South, and the Age of Emancipation". Journal of World History 14, n. ${ }^{\circ} 2$ (2003): 209-241.

Harris, John A. E. "Circuits of wealth, circuits of sorrow: financing the illegal transatlantic slave trade in the age of suppression, 1850-66". Journal of Global History 11, n. ${ }^{\circ} 3$ (2016): 409-429.

Harvey, David. A brief history of neoliberalism. Oxford: Oxford University Press, 2005. . El enigma del capital y las crisis del capitalismo. Madrid: Akal, 2012.

Hausberger, Bernd and Erika Pani. "Historia global. Presentación”. Historia Mexicana, 68, n. ${ }^{\circ} 1$ (2018): 177-196.

. Historia mínima de la globalización temprana, Ed. El Colegio de México, México, $2018 b$.

Hobsbawm, Eric. Sobre historia. Barcelona: Crítica-Grijalbo, 1998.

. "First world and third world after the cold war". CEPAL Review, (1999): 7-14.

Irigoin, Alejandra. "The End of a Silver Era: The Consequences of the Breakdown of the Spanish Peso Standard in China and the United States, 1780s-1850s". Journal of World History 20, n. ${ }^{\circ} 2$ (2009): 207-244. 
Johnson, Bob. "Globalizing the Harlem Renaissance: Irish, Mexican, and 'Negro' renaissances in The Survey, 1919-1929”. Journal of Global History 1, n. ${ }^{\circ} 2$ (2006): 155-175.

Kalter, Christoph. "From global to local and back: the 'Third World' concept and the new radical left in France". Journal of World History 12, n. ${ }^{\circ} 1$ (2017): 115-136.

Kelly, Patrick William. "The 1973 Chilean coup and the origins of transnational human rights activism”. Journal of Global History 8, n. ${ }^{\circ} 1$ (2013): 165-186.

Karttunen, Frances. "After the Conquest: Survival of Indigenous Patterns of Life and Belief”. Journal of World History 3, n. ${ }^{\circ} 2$ (1992): 239-256.

Lawson, George. Negotiated Revolutions. The Czech Republic, South Africa and Chile. Aldershot: Ashgate, 2005.

Lenin, V.I. "Una caricatura del marxismo y el "economismo imperialista". In Obras completas, 26-80. Madrid: Akal, 1977.

Lopes Don, Patricia. "Franciscans, Indian Sorcerers, and the Inquisition in New Spain, 15361543". Journal of World History 17, n. ${ }^{\circ} 1$ (2006):27-48.

Love, Joseph L. Crafting the Third World. Theorizing Underdevelopment in Rumania and Brazil. California: Stanford University Press, 1996.

Lu, Sidney X. "Japanese American Migration and the Making of model Women for Japanese Expansion in Brazil and Manchuria, 1871-1945”. Journal of World History 28, n. ${ }^{\circ} 3$ \& 4 (2017): 437-467.

Mallon, Florencia E. "The Promise and Dilema of Subaltern Studies: Prespectives from Latin American History". The American Historical Review 99, n. ${ }^{\circ} 5$ (1994): 1491-1515.

Martel, H.E. "Hans Staden's Captive Soul: Identity, Imperialism, and Rumors of Cannibalism in Sixteenth-Century Brazil”. Journal of World History 17, n. ${ }^{\circ} 1$ (2006): 51-69.

Mignolo, Walter D. Historias locales/diseños globales. Colonialidad, conocimientos subalternos y pensamiento fronterizo. Madrid: Akal, 2003.

Moses, Julia y Martin Dauton. "Editorial- border crossing: global dynamics of social policies and problems". Journal of Global History 9, n. ${ }^{\circ} 2$ (2014): 177-188.

Muldoon, James. "Solorzano's 'De indiarum iure': Applying a Medieval Theory of World Order in the Seventeenth Century". Journal of World History 2, n. ${ }^{\circ} 1$ (1991): 29-45.

Mulich, Jeppe. "Microregionalism and intercolonial relations: the case of the Danish West Indies, 1730-1830”. Journal of Global History 8, n. ${ }^{\circ} 1$ (2013): 72-94. 
Muse-Fisher, John. "Financing a new nation: a comparative study of the financial roots of the USA and Gran Colombia”. Journal of Global History 7, n. ${ }^{\circ} 1$ (2012): 3-26.

Ortega, José Guadalupe. "Machines, modernity, and sugar: the Greater Caribbean in a global context, 1812-50”. Journal of Global History 9, n. ${ }^{\circ} 1$ (2014):1-25.

Palley Thomas I. "Three globalizations, not two: Rethinking the history and economics of trade and globalization". FMM Working Paper 18 (2018), March Hans-Böckler Stiftung.

Palmer, Colin A. "From Africa to the Americas: Ethnicity in the Early Black Communities of the Americas". Journal of World History 6, n. ${ }^{\circ} 2$ (1995): 223-236.

Pareault, Melanie. "To Fear and to Love Us': Intercultural Violence in the English Atlantic". Journal of World History 17, n. ${ }^{\circ} 1$ (2006): 71-93.

Parron, Tâmis. "The British Empire and the Suppression of the Slave Trade to Brazil: A Global History Analysis". Journal of World History 29, n. ${ }^{\circ} 1$ (2018): 1-36.

Phillips, William D. Jr. "Africa and the Atlantic islands Meet the Garden of Eden: Christopher Columbus's View of America”. Journal of World History 3, n. ${ }^{\circ} 2$ (1992):149-164.

Piette, Adam. "Writing into the Cold War West". Theory, Culture \& Society 28, n. ${ }^{\circ}$ 7-8 (2011): 390-395.

Podgorny, Irina. "The elk, the ass, the tapir, their hooves, and the falling sickness: a story of substitution and animal medical substance". Journal of Global History 13, n. ${ }^{\circ} 1$ (2018): 46-68.

Prak, M. "The Cambridge history of capitalism Vol.1 The rise of capitalism: from ancient origins to 1848; vol. 2: The spread of capitalism: from 1848 to the present by Larry Neal and Jeffrey G. Williamson”. Journal of Global History 10, n. ${ }^{\circ} 3$ (2015): 506-508.

Prebisch, Raúl. "El desarrollo económico de la América Latina y algunos de sus principales problemas”. El Trimestre Económico 63: n. ${ }^{\circ} 249$ (1996):175-245.

Prestholdt, Jeremy. "Resurrecting Che: radicalism, the transnational imagination, and the politics of heroes". Journal of Global History 7, n. ${ }^{\circ} 3$ (2012): 506-526.

Quijano, Aníbal. Cuestiones y horizontes. De la dependencia histórico-estructural a la colonialidad/descolonialidad del poder. Buenos Aires: Colección Antologías-Consejo Latinoamericano de Ciencias Sociales, 2014.

Richard, Anne-Isabelle. "Competition and complementarity: civil society networks and the question of decentralizing the League of Nations". Journal of Global History 7, n. ${ }^{\circ} 2$ (2012): 223-256. 
Rimmer, Steffen. "Chinese abolitionism: the Chinese Education Mission in Connecticut, Cuba and Peru". Journal of Global History 11, n. ${ }^{\circ} 3$ (2016): 344-364.

Riojas, Carlos. "Desafíos de la historia global: Una perspectiva desde América Latina". In Retos y perspectivas del desarrollo económico en Ecuador y América Latina, compiled by Instituto de Investigaciones Económicas y Políticas, 389-400. Guayaquil: Centro de Investigación y Desarrollo de Ecuador - CIDE, 2017.

. "América Latina entre narrativas influyentes y tiempos de historia global". América Latina en la Historia Económica 26, n. ${ }^{\circ} 3$ (2018): 7-39.

"Luces y sombras sobre América Latina en una historia global. Esboços, Florianópolis 26, n. ${ }^{\circ} 41$ (2019): 29-53.

Rivarola Puntigliano, Andrés and Örjan Appelqvist. "Prebisch and Myrdal: development economics in the core and on the periphery". Journal of Global History 6, n. ${ }^{\circ} 1$ (2011): 29-52.

Rochlin, James F. "Who said the Cold War is over? The political economy of strategic conflict between Venezuela and Colombia". Third World Quarterly 32, n. ${ }^{\circ} 2$ (2001): 237-260.

Rogers, Paul. "A century of the edge: from Cold War to hot world, 1945-2045”. International Affairs 90, n. ${ }^{\circ} 1$ (2014): 93-106.

Rosemblatt, Karin Alejandra. "Modernization, dependency, and the global in Mexican critiques of anthropology". Journal of Global History 9, n. ${ }^{\circ} 1$ (2014): 94-121.

Ross, Kristin. Mai 68 et ses vie ultérieures. Paris: Agone, 2010.

Rupprecht, Tobias. "Socialist high modernity and global assignation: a shared history of Brazil and the Soviet Union during the Cold War". Journal of Global History 6, n. ${ }^{\circ} 3$ (2011): 505-528.

Sackley, Nicole. "The village as Cold War site: experts, development, and the history of rural reconstruction". Journal of Global History 6, n. ${ }^{\circ} 3$ (2011): 481-504.

Sanders, James E. "Atlantic Republicanism in Nineteenth-Century Colombia: Spanish America's Challenge to the Contours of Atlantic History". Journal of World History 20, n. ${ }^{\circ} 1$ (2009): 131-150.

Sauvy, Alfred. “Trois Mondes, Une planète”. L'Observateur, n. ` 118 (1952).

Schilling, Annegreth. "Between context and conflict: the 'boom' of Latin American Protestantism in the ecumenical movement (1955-75)". Journal of Global History 13, n. ${ }^{\circ} 1$ (2018): 274-293. 
Schramm, Christina. "Estado, justicia y libertad. Aportes al pensamiento político desde Ditsö Káska y la diáspora africana”. Anuario CIEP 4 (2014): 24-49.

Schuster, Sven. "The world's fairs as spaces of global knowledge: Latin American archaeology and anthropology in the age of exhibitions". Journal of Global History 13, n. ${ }^{\circ} 1$ (2018): 69-93.

Semo, Enrique. Historia del capitalismo en México: Los orígenes: 1521/1763, México: Era, 1973.

Shepard, Todd. "Algeria, France, Mexico, UNESCO: a transnational history of antiracism and decolonization, 1932-1962”, Journal of Global History 6, n. ${ }^{\circ} 1$ (2011): 273-297.

Shlomowitz, Ralph and Lance Brennan. "Epidemiology and Indian Migration at Home and Abroad". Journal of World History 5, n. ${ }^{\circ} 1$ (1994): 47-67.

Simensen, Jarle. «Democracy and globalization: Nineteen eighty-nine and the "Third Wave"». Journal of World History 10, n. ${ }^{\circ} 2$ (1999): 391-411.

Slack JR, Edward R. "The Chinos in New Spain: A Corrective Lens for a Distorted Image". Journal of World History 20, n. ${ }^{\circ} 1$ (2009): 35-67.

Smaldone, William. "Socialist Paths in a Capitalist Conundrum: Reconsidering the German Catastrophe of 1933". Journal of World History 18, n. ${ }^{\circ} 3$ (2007): 297-323.

Strasser, Ulrike and Heidi Tinsman. 'It's a Man's World? World History Meets the History of Masculinity, in Latin American Studies, for Instance". Journal of World History 21, n. ${ }^{\circ} 1$ (2010): 75-96.

Strasser, Ulrike. "A case of empire envy? German Jesuits meet an Asian mystic in Spanish America". Journal of Global History 2, n. ${ }^{\circ} 1$ (2007): 24-40.

Subrahmanyam, Sanjay. "Connected history: notes towards a reconfiguration of early modern Eurasia". Modern Asian Studies 31, n. ${ }^{\circ} 3$ (1997): 735-762.

Sunkel, Osvaldo and Pedro Paz. El subdesarrollo latinoamericano y la teoría del desarrollo, México: Siglo XXI, 1991.

Taylor, Lucy. "Global perspective on Welsh Patagonia: the complexities of being both colonizer and colonized”. Journal of Global History 13, n. ${ }^{\circ} 3$ (2018): 446-468.

Tezcan, Baki. "Law in China or Conquest in the Americas: Competing Constructions of Political Space in the Early Modern Ottoman Empire". Journal of World History 24, n. o 1 (2013): 107-134. 
Thompson, William R. "The Military Superiority Thesis and the Ascendancy of Western Eurasia in the World System”. Journal of World History 10, n. ${ }^{\circ} 1$ (1999): 143-178.

Thornton, John K. «"I am the Subject of the King of Congo": African Political Ideology and the Haitian Revolution». Journal of World History 4, n. ${ }^{\circ} 2$ (1993): 181-214.

Tuffnell, Stephen. "Engineering inter-imperialism: American miners and the transformation of global mining, 1871-1910”. Journal of Global History 10, n. ${ }^{\circ} 1$ (2015): 53-76.

Van Deusen, Nancy E. "Indios on the move in the sixteenth-century Iberian world". Journal of Global History 10, n. ${ }^{\circ} 3$ (2015): 387-409.

$\mathrm{Xu}$, Lou. "Reconstructing world history in the People's Republic of China since the 1980s". Journal of World History 18, n. ${ }^{\circ} 3$ (2007): 325-350.

Zinsser, Judith P. "From Mexico to Copenhagen to Nairobi: The United Nations Decade for Women, 1975-1985”. Journal of World History 13, n. ${ }^{\circ} 1$ (2002): 139-168. 